\title{
From flames to inflammation: how wildfires affect patterns of wildlife disease
}

\author{
Gregory F. Albery ${ }^{1 *}$, Isabella Turilli ${ }^{1}$, Maxwell B. Joseph ${ }^{2}$, Janet Foley ${ }^{3}$, Celine H. Frere ${ }^{4}$ and Shweta Bansal ${ }^{1}$
}

\begin{abstract}
Background: Fire strongly affects animals' behavior, population dynamics, and environmental surroundings, which in turn are likely to affect their immune systems and exposure to pathogens. However, little work has yet been conducted on the effects of wildfires on wildlife disease. This research gap is rapidly growing in importance because wildfires are becoming globally more common and more severe, with unknown impacts on wildlife disease and unclear implications for livestock and human health in the future.

Results: Here, we discussed how wildfires could influence susceptibility and exposure to infection in wild animals, and the potential consequences for ecology and public health. In our framework, we outlined how habitat loss and degradation caused by fire affect animals' immune defenses, and how behavioral and demographic responses to fire affect pathogen exposure, spread, and maintenance. We identified relative unknowns that might influence disease dynamics in unpredictable ways (e.g., through altered community composition and effects on free-living parasites). Finally, we discussed avenues for future investigations of fire-disease links.

Conclusions: We hope that this review will stimulate much-needed research on the role of wildfire in influencing wildlife disease, providing an important source of information on disease dynamics in the wake of future wildfires and other natural disasters, and encouraging further integration of the fields of fire and disease ecology.
\end{abstract}

Keywords: Animal ecology, Behavior, Disease ecology, Ecoimmunology, Global change, Infectious disease, Parasites

\footnotetext{
* Correspondence: gfalbery@gmail.com

'Department of Biology, Regents Hall, Georgetown University, 37th and O

Streets NW, Washington, DC 20057-1229, USA

Full list of author information is available at the end of the article
}

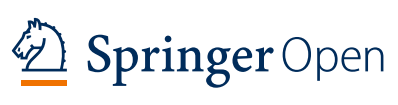

(c) The Author(s). 2021 Open Access This article is licensed under a Creative Commons Attribution 4.0 International License, which permits use, sharing, adaptation, distribution and reproduction in any medium or format, as long as you give appropriate credit to the original author(s) and the source, provide a link to the Creative Commons licence, and indicate if changes were made. The images or other third party material in this article are included in the article's Creative Commons licence, unless indicated otherwise in a credit line to the material. If material is not included in the article's Creative Commons licence and your intended use is not permitted by statutory regulation or exceeds the permitted use, you will need to obtain permission directly from the copyright holder. To view a copy of this licence, visit http://creativecommons.org/licenses/by/4.0/. 


\section{Resumen}

Antecedentes: Los fuegos afectan fuertemente el comportamiento animal, su dinámica poblacional y su entorno ambiental, lo que a su vez probablemente afecte su sistema inmune y exposición a patógenos. Sin embargo, muy pocos trabajos han sido desarrollados sobre los efectos de los incendios en las enfermedades de la fauna silvestre. Esta brecha en la información científica está creciendo rápidamente, pues los incendios a nivel global están siendo más comunes y más severos, con impactos desconocidos en las enfermedades de la fauna silvestre y sin claras implicancias futuras sobre la salud humana y del ganado doméstico.

Resultados: Discutimos acá cómo los incendios pueden influenciar la susceptibilidad y exposición a infecciones en animales silvestres, y las consecuencias potenciales para la ecología y la salud pública. En nuestro marco de referencia, delineamos cómo la pérdida de hábitat y la degradación causada por los incendios afecta las defensas del sistema inmune de los animales silvestres, y cómo las respuestas de comportamiento y demográficas afectan la exposición, diseminación, y mantenimiento del patógeno. Identificamos factores relativamente desconocidos que podrían influenciar la dinámica de las enfermedades de manera no predecible (i.e., a través de alteraciones en la composición de la comunidad y efectos sobre parásitos de vida independiente). Finalmente, discutimos vías para futuras investigaciones de vínculos entre fuegos y enfermedades.

Conclusiones: Esperamos que esta revisión estimule la necesidad de contar con investigaciones sobre el rol de los incendios en su influencia sobre las enfermedades de la fauna silvestre, proveyendo una fuente de información importante sobre la dinámica de las enfermedades en la ocurrencia de futuros incendios y otros desastres naturales, y propiciando una mayor integración futura de los campos del fuego y la ecología de enfermedades.

\section{Introduction}

We inhabit an increasingly fire- and disease-prone world. As the climate warms, many ecosystems are experiencing hotter temperatures, earlier springs, and dry seasons of unprecedented length and severity, which have inevitably led to a steady global increase in the frequency and extent of wildfires (Westerling et al. 2006; Dennison et al. 2014; Jolly et al. 2015; Westerling 2016; Kelly et al. 2020; Stephens et al. 2020; Ward et al. 2020; Nimmo et al. 2021). Exacerbating the problem, humans have further influenced when and where fires occur by altering fuel availability and igniting fires, both intentionally (e.g., with agricultural burning; Korontzi et al. 2006) and unintentionally (e.g., through campfires; Balch et al. 2017). Simultaneously, anthropogenic disturbances such as human traffic, habitat loss, degradation, and fragmentation have altered patterns of animal and human health. The changing climate and the ongoing conversion of wild land for human purposes have led to increasing cross-species parasite transmission, such that the burden of wildlife disease is being foisted upon human and livestock populations (Jones et al. 2008; Morse et al. 2012) and vice versa (Fagre et al. 2021). To highlight just a few mechanisms, habitat destruction and climate-associated range shifts create novel contacts among displaced wildlife, livestock, and humans (Carlson et al. 2020a; Gibb et al. 2020); the loss of parasite diversity destabilizes parasite communities and increases the risk that an animal will transmit one of those parasites to human populations (Carlson et al. 2017; Sweeny et al. 2020); and anthropogenic environments alter population dynamics and host immunity, leading animals to host greater burdens and diversities of parasites (Murray et al. 2019; Gibb et al. 2020; Werner and Nunn 2020; Albery et al. 2021a). The growing appreciation of these interconnections has led to a rise in "One Health" thinking, which focuses on the relationships between environment, animal, and human health, with the central tenet that achieving the best results for any one element of these three domains must take the other two into account (Mackenzie et al. 2013; Gibbs 2014). Despite the well-appreciated importance of environmental disturbances in driving patterns of disease, the role of fires remains surprisingly underexplored.

As yet, relatively few studies have explicitly examined links between fire and wildlife disease or summarized their implications (but see Scasta 2015). This sparsity is surprising, given that wildfires fulfill many of the requirements for potentially important disease drivers. Wildfires can profoundly shape the landscape both acutely and in the long term (Dennison et al. 2014; Block et al. 2016; Ward et al. 2020); they alter wildlife population dynamics by altering movement and mortality patterns (Banks et al. 2011; Ecke et al. 2019; Pausas 2019; Harris et al. 2020); and they have a number of direct physiological effects (Erb et al. 2018; Joordaan et al. 2019). These effects could have a range of impacts on patterns of wildlife disease; indeed, many of the studies of fire's disease consequences found a complex set of positive and negative responses to fire that imply a rich set of underlying mechanisms (Hossack et al. 2013a; Sokos et al. 2016; Hing et al. 2017; Ecke et al. 2019). 
Why, then, have there been so few studies of wildfire and wildlife disease? Part of this absence may be due to the relative rarity of wildfires and their confinement to a specific few fire-prone areas, and to a lack of focus on fire impacts on animals relative to plants (Pausas 2019), despite some attention paid to plant diseases specifically (Simler-Williamson et al. 2021). Many of the studies that have been conducted on the disease impacts of wildfire have focused on fire's direct, first-order impacts on environmental parasites themselves (reviewed in Scasta 2015), without necessarily considering fire's many demographic, behavioral, and physiological consequences for the host. Of the handful of studies that have found differences between host-parasite communities in burned versus unburned contexts (e.g., Hossack et al. 2013a; Torre et al. 2013; Ecke et al. 2019), underlying mechanisms are often unclear. A range of mechanisms potentially link fire with downstream disease consequences, many of which remain implicit, unexplored, or unevidenced. Additionally, as yet, it is unclear how these drivers might compare in magnitude and direction, and how these trends could vary across different hosts, parasites, and ecological contexts. As such, there is a growing need for an integrative framework for conceptualizing fire-disease interactions in wild animals to grasp the implications of an increasingly flammable world.

Here, we established a framework for known and hypothesized impacts of wildfires on wildlife disease. We outlined how fires could alter host immunity, behavior, and population dynamics, presenting hypotheses for their effects on wildlife disease. Where possible, we provided evidence for the links that we describe, and we discussed the reasons for evidence gaps when they occurred. Finally, we identified potential empirical study systems and methodologies that could help to illuminate and provide evidence for these diverse effects, and outlined future directions to anticipate fire's implications for wildlife and human disease in the future. We aimed for this review to provoke increased integration between the disparate fields of fire ecology and disease ecology, acting both as a disease ecology primer for fire ecologists and as a hypothesis-generating exercise for disease ecologists working in fire-prone areas. Ultimately, we aimed to encourage a range of exciting investigations, allowing us to more easily anticipate the One Health consequences of global change in the near future.

\section{The framework}

Predicting how fires will alter patterns of wildlife disease first requires a framework of potential pathways and interactions. We provided one by considering an expansive set of fire-related ecological effects and combined it with conventional knowledge about the drivers of ecological disease dynamics (Fig. 1), accompanied by a selection of fire- and disease-specific studies in wild animals (Table 1). In this section, we described these links in detail, outlining which have prior evidence and which await empirical support. These mechanisms all influence disease principally through one of two broad pathways: either by altering exposure to parasites (habitat destruction, mortality, host movement, and community alteration) or by altering immune-mediated susceptibility (stress or injury and pollution).

Before outlining the framework, we accentuate that this review is predicated on a relatively simplified selection of scenarios. Fire is highly multivariate and context dependent, and its impacts on wildlife can vary heavily between animal species, fire types, environmental contexts, and more (Engstrom 2010; Hossack et al. 2013a; Block et al. 2016). As such, it is very difficult to draw generalizations or to make predictions except in a very well-understood, specific circumstance, even before considering the complexity of downstream implications for infection. When predicting these interactions in a given system, the processes at play will be subject to previous rules concerning the behavioral, physiological, and demographic consequences of fire, which are comparatively well understood (Engstrom 2010). In particular, fire regimes could have a strong impact on the observed dynamics; some fire-adapted ecosystems have been subject to regular burns for much of their existence, while, under global change, these regimes are shifting quickly and areas that are poorly adapted to fire are beginning to burn. The relative importance of these processes and their balance in determining host disease burdens will further depend on the host-parasite system (Hossack et al. 2013a; Torre et al. 2013). Our aim here was not to provide final predictions for the impacts of fire on any one system but to outline a generalized framework that can be used to unpick patterns and test hypotheses concerning fire and disease in the future. For this reason, we have been sure to note explicitly which links have empirical support and which represent reasoned hypotheses that we are putting forward or reiterating (Fig. 1).

\section{Habitat destruction and modification}

Habitat modification is first and foremost among fire's effects (Block et al. 2016; Sokos et al. 2016; Ward et al. 2020; Wan et al. 2020). Depending on the fire's type, severity, extent, and length, it will burn non-resistant vegetation, including most non-woody plants in the vicinity, which will alter the available resources and movement corridors formed by these plants (Fisher and Wilkinson 2005). The loss of vegetation in an animal's range will reduce access to shelter such that surviving individuals have fewer opportunities to eat, nest, thermoregulate, and hide from predators. Some species preferentially inhabit certain microhabitats such as snags (standing dead 


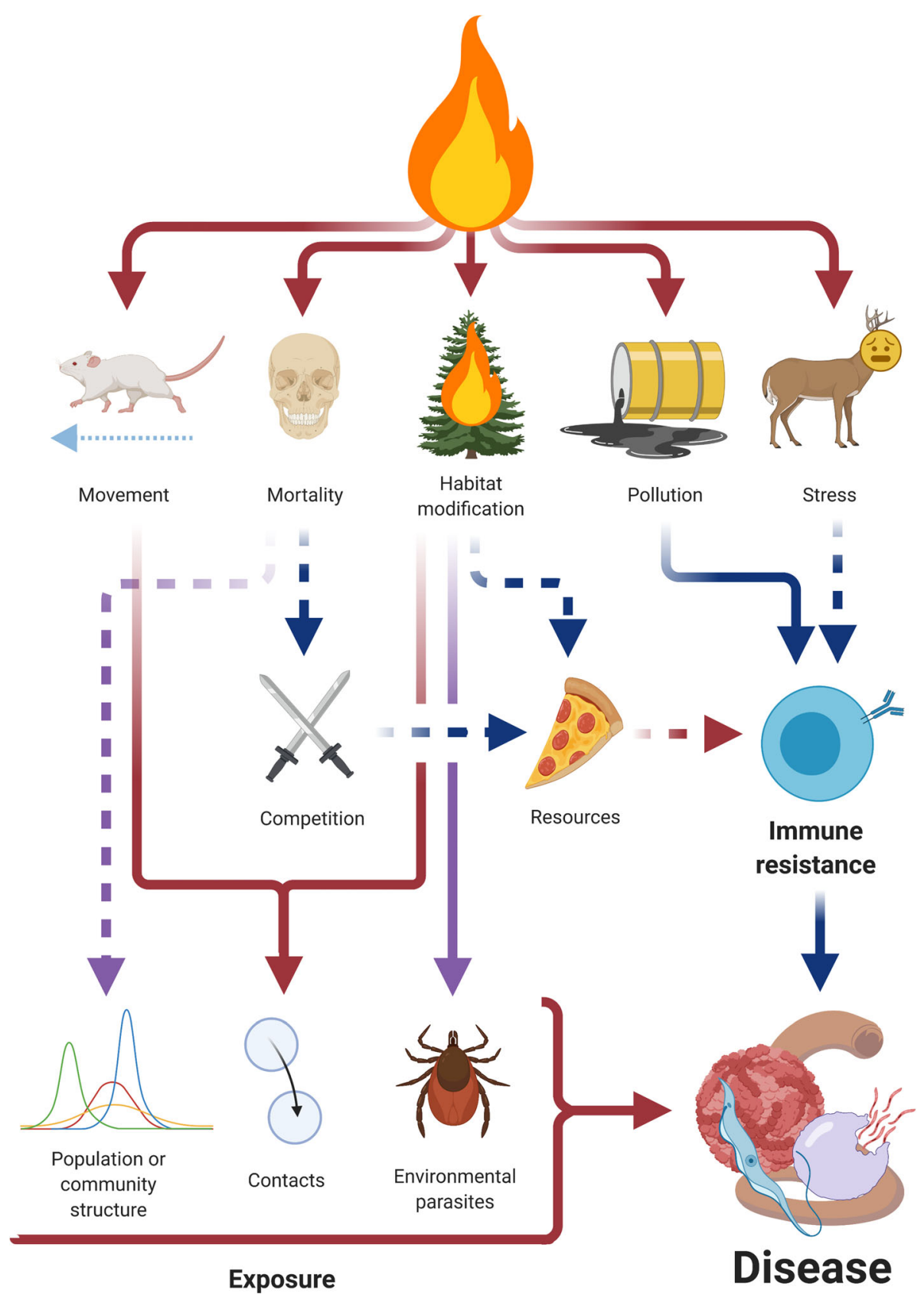

Fig. 1 Our framework for fire's potential effects on wildlife disease, detailing a series of hypothetical and proven links between factors, as evidenced by previously published research (from 2000 to 2020) on relationships between fire and wildlife disease. We provide a variety of mechanisms by which fire could affect either exposure or susceptibility to infection according to a priori understanding of fire and disease systems, including positive, negative, and neutral effects. Red arrows denote positive, exacerbating, or increasing relationships; blue arrows denote negative, inhibitory, or decreasing relationships. Purple arrows denote relationships that could be either positive or negative depending on the situation. Solid lines denote mechanisms that have been demonstrated in the literature; dotted lines are strongly expected given links in non-fire-related systems but have not yet been shown to link fire with downstream disease consequences. Relationships are displayed in a pairwise fashion, so complex links must be followed along the different link colors. For example, because resources and immunity are positively correlated (red line), habitat destruction (which depletes resources; blue line) is expected to decrease immunity. Image created with BioRender.com

or dying trees) that may be especially vulnerable to burning (Lydersen et al. 2019), while others may be less able to find sufficient food (Mardiastuti 2020), leading to poor nutrition and lower condition. Nutrition quality and quantity are integral determinants of the immune response (Becker and Hall 2014; Altizer et al. 2018; 
Table 1 Previously published evidence (from 2000 to 2020) for relationships between fire and wildlife disease. We set out to identify studies that tested links between wildfire, prescribed fire, or elements of fire exposure in wild and captive animals. Our search uncovered a selection of effects and mechanisms, including positive, negative, and neutral effects, providing some evidence for elements of our fire-disease framework. In the "effect" column, plus sign (+) denotes positive, exacerbating, or increasing relationships; minus sign (-) denotes negative, inhibitory, or decreasing relationships. Findings in parentheses denote an effect on immunity but no proven impact on disease; plus/minus sign (+/-) denotes a combination of positive and negative effects; zero (0) denotes no detected effect. For each example, we include the location, the pyrosystem (the type of fire and the vegetation involved), the animal, and the parasite involved. We also include the explanation for the observed pattern; when there was no detected effect of fire on disease, no explanation is given and the cell is left blank

\begin{tabular}{|c|c|c|c|c|}
\hline $\begin{array}{l}\text { Reference } \\
\text { pyrosystem }\end{array}$ & Hosts & $\begin{array}{l}\text { Pathogen or immune } \\
\text { metric }\end{array}$ & Effect & Suggested mechanism \\
\hline
\end{tabular}

Parker-Fann 2020

Virginia, USA, forest; prescribed burn treatment

$\begin{array}{ll}\text { Migrating birds, mammals through tick vector } & \text { Borrelia burgdorferi } \\ \text { Ixodes Latreille, } 1795 \text { sp. } & \text { Johnson et al. } 1984 \\ & \text { emend. Baranton et al. } \\ & 1992\end{array}$

emend. Baranton et al.

Pascoe et al. 2020

California, USA, blue oak (Quercus douglasii Hook. \& Arn) woodland vegetation; major fire sparked by vehicle exhaust

Rodents, small mammals through tick vectors Ixodes sp., Dermacentor C.L.Koch, 1844 sp.
Borrelia burgdorferi,

Anaplasma

phagocytophilum (Foggie

1949) Dumler et al. 2001

Ecke et al. 2019

Sweden coniferous forest; major fire after fire-suppression regime

Bank vole (Myodes glareolus)

Puumula orthohantavirus +

Destruction of environmental parasites

Jones et al. 2018

Western Australia bushland; intense ground and canopy bushfire

Woylie (Bettongia peniciallata)

Ticks and lice

0

MacDonald et al. 2018

Southern California, USA, oak woodland; major fire sparked by cooking site

\begin{tabular}{|c|c|c|c|}
\hline $\begin{array}{l}\text { Western fence lizard (Sceloporus occidentalis } \\
\text { Baird and Girard, 1852), dusky-footed woodrat } \\
\text { (Neotoma fuscipes Baird, 1858), California mule } \\
\text { deer (Odocoileus hemionus californicus Caton, } \\
\text { 1876) }\end{array}$ & Borrelia burgdorferi & $+/-$ & $\begin{array}{l}\text { Changes in competent host composition, and } \\
\text { environmental parasite destruction }\end{array}$ \\
\hline $\begin{array}{l}\text { Western fence lizard through tick vector Ixodes } \\
\text { pacificus Cooley \& Kohls, } 1943\end{array}$ & Borrelia burgdorferi & 0 & \\
\hline $\begin{array}{l}\text { Deer mouse (Peromyscus maniculatus Wagner, } \\
\text { 1845) through tick vector Ixodes pacificus }\end{array}$ & Borrelia burgdorferi & 0 & \\
\hline $\begin{array}{l}\text { Dusky-footed woodrat through tick vector } \\
\text { Ixodes pacificus }\end{array}$ & Borrelia burgdorferi & - & $\begin{array}{l}\text { Fire significantly reduced pathogen reservoir } \\
\text { host population }\end{array}$ \\
\hline $\begin{array}{l}\text { California mule deer through tick vector Ixodes } \\
\text { pacificus }\end{array}$ & Borrelia burgdorferi & - & $\begin{array}{l}\text { Fire reduced host activity, decreasing tick } \\
\text { populations and negatively impacting pathogen } \\
\text { transmission }\end{array}$ \\
\hline
\end{tabular}

Ortega 2018

Florida, USA, wiregrass (Aristida stricta Michaux), pine (Pinus L. spp.) straw, myrtles (Myrica cerifera L.), saw palmettos (Serenoa repens [Bartram] J.K.Small); prescribed burn treatment

Cuban tree frog (Osteopilus septentrionalis Trueb \& Tyler, 1974)

Cuban tree frog

Cuban tree frog
Aplectana sp. nematode

Acuariid nematodes

Trematode metacercariae
Burns kill larvae in the soil while also reducing recruitment to adult subpopulation

$+\quad$ Acuariid nematode abundance increases as arthropod diversity or abundance increase postfire, facilitating predation by birds needed for the Acuariid life cycle

Burns enhance freshwater productivity, and are hence beneficial to freshwater snails, that are the 
Table 1 Previously published evidence (from 2000 to 2020) for relationships between fire and wildlife disease. We set out to identify studies that tested links between wildfire, prescribed fire, or elements of fire exposure in wild and captive animals. Our search uncovered a selection of effects and mechanisms, including positive, negative, and neutral effects, providing some evidence for elements of our fire-disease framework. In the "effect" column, plus sign (+) denotes positive, exacerbating, or increasing relationships; minus sign (-) denotes negative, inhibitory, or decreasing relationships. Findings in parentheses denote an effect on immunity but no proven impact on disease; plus/minus sign (+/-) denotes a combination of positive and negative effects; zero (0) denotes no detected effect. For each example, we include the location, the pyrosystem (the type of fire and the vegetation involved), the animal, and the parasite involved. We also include the explanation for the observed pattern; when there was no detected effect of fire on disease, no explanation is given and the cell is left blank (Continued)

\begin{tabular}{lll}
\hline $\begin{array}{l}\text { Reference Hosts } \\
\text { pyrosystem }\end{array}$ & $\begin{array}{l}\text { Pathogen or immune Effect Suggested mechanism } \\
\text { metric }\end{array}$
\end{tabular}

intermediate hosts

Black et al. 2017

Northern California, USA, forests; major fires in regular fire regime

$\begin{array}{lcl}\text { Rhesus macaque monkey (Macaca mulatta } & \text { Immune regulation } & (+) \quad \begin{array}{l}\text { Negative impact of wildfire smoke exposure in } \\ \text { monkeys }\end{array}\end{array}$

Sokos et al. 2016

Greece Aleppo pines (Pinus halepensis, Miller), broadleaf shrubs, and agricultural fields; moderate and severe fires

Brown hare (Lepus europaeus Pallas, 1778) $\quad \begin{aligned} & \text { European Brown Hare } \\ & \text { Syndrome virus }\end{aligned}$

Bowen et al. 2015

Central California, USA, chaparral and oak woodland; major fire in regular fire regime

$$
\text { Sea otter (Enhydra lutris) Immune transcriptomics }
$$

(+) Pyrogenic chemicals require changes in immune expression to detoxify

Fuentes et al. 2010

Spain forests and cultivated land; major fire in regular fire regime

$\begin{array}{ll}\text { Wood mouse (Apodemus sylvaticus Linnaeus, Helminths } & 0 \\ 1758) & \end{array}$

Hossack et al. $2013 b$

Montana, USA, wetlands; regular fire regimes

Boreal toad (Anaxyrus boreas boreas)

Hossack et al. 2013a

Montana, USA, wetlands; regular fire regimes Long-toed salamander (Ambystoma
macrodactylum Baird, 1950)

Columbia spotted frog (Rana pretiosa luteiventris Thompson, 1913)

\section{Chytrid fungus} (Batrachochytrium dendrobatidis)
0

(1) 
showed that a reduction in available foraging habitats was associated with substantially reduced survival prospects (Baranowski et al. 2020). The bats also had to newly compete with black flying foxes (Pteropus alecto Termminck, 1837) for resources within their new fire-induced habitat (Baranowski et al. 2020). The proximate mechanisms leading to these fitness deficits are unclear, but living in unsuitable habitats is often associated with increased disease (e.g., in bumblebees [Bombus impatiens Cresson, 1863]; McNeil et al. 2020). Disease is therefore a feasible explanation for reduced fitness in fire-altered landscapes that deserves investigation where all three (fire, disease, and fitness) are quantifiable.

\section{Effects on free-living parasites}

Fire's destructive effects are not restricted to vegetation: the flames may also kill or inactivate parasites in the environment, which could reduce the ecosystem's burden of disease on a massive scale, such that animals are less often exposed and therefore exhibit lower burdens (reviewed in Scasta 2015). Fundamentally, this process may be most relevant for parasites that exhibit longlived environmental stages such as ticks, soil-transmitted helminths (parasitic worms), or spore-forming bacteria. However, there is some variation in fire susceptibility within these categories, and environmentally latent parasites often exhibit surprising hardiness to ecological insults. For example, although ticks spend long periods in the environment and should have little protection against a blaze, in fires in Californian, USA, they have been shown to be capable of surviving in soil refugia (MacDonald et al. 2018). The majority of studies that we found that examined environmental parasite destruction examined ectoparasites (and some helminths), rather than microparasites such as viruses, bacteria, and protozoa. Additionally, they rarely included measures of host burdens alongside environmental parasite counts (e.g., tick counts on trapped rodents alongside those obtained through tick dragging in the environment).

It is important to note that even the destruction of environmental parasites will not necessarily be universally beneficial for a population's disease burden. Multiple parasite species often exist as a mixed community that interacts through their hosts' behavior and immune systems, and removing one parasite could paradoxically worsen infection with another by destabilizing this community (Pedersen and Fenton 2007; Telfer et al. 2010; Budischak et al. 2018). Coinfection dynamics and parasite community interactions are important for determining host resistance (Sweeny et al. 2020) and fitness (Telfer et al. 2010). Perturbing one aspect of the system-namely, by removing all environmental ticks and helminths-is unlikely to leave the rest of the parasite community unperturbed. For example, a study in Peromyscus Gloger, 1841 mice found that experimental removal of gastrointestinal helminths resulted in increased prevalence of zoonotic Sin Nombre virus (SNV; Sweeny et al. 2020). When wildfires reduce environmental loads or diversities of helminth communities (Torre et al. 2013), the consequences for other infections could be unpredictable. Coinfection dynamics in the wild are the rule rather than the exception (Pedersen and Fenton 2007), and it is therefore possible that the wide removal of environmental parasites will merely lend a hand to the other parasites in the system.

Rather than destroying parasites, fire may sufficiently modify the environment that parasites are less able to develop and achieve onward transmission, similar to its implications for hosts' microclimates (see above); this was suggested to be the case with chytrid fungus (Batrachochytrium dendrobatidis Longcore, Pessier \& Nichols 1999) infection in boreal toads (Anaxyrus boreas boreas Baird and Girard, 1852) (Hossack et al. 2013b). A recent analysis found that fires in South African grasslands have widespread effects on fungal and bacterial communities, through a combination of altered elemental composition, microclimate, and vegetation (Vermeire et al. 2021). On the other hand, fire could create environmental conditions that exacerbate pathogen transmission. For example, smoke and changes in air currents could increase the transmission of dust-borne pathogens like Coccidioides G.W.Stiles, 1896 (Pearson et al. 2019). Smoke has been suggested as an important dispersal agent for a wide range of bacterial and fungal pathogens, with uncertain consequences to date (Kobziar and Thompson 2020). In sum, the direct effects of fire on a given pathogen's survival and transmission in the environment could range from total extirpation to a massive transmission bonus, depending on the pathogen's biology. As such, the previous focus on fire as an environmentcleansing force that will reduce the environmental burden of parasites may not necessarily be warranted, and ecologists should avoid assuming that a recently burned area will have few environmental parasites.

\section{Host mortality}

The heat and disturbance of fire can kill or directly injure animals (Erwin and Stasiak 1979; Kelly et al. 2015; Joordaan et al. 2019; Harris et al. 2020), which could have several non-exclusive impacts on disease. Perhaps surprisingly, we suggest that these mortality effects will mostly reduce the burden of disease because they often decrease population density in the affected area (Dawson et al. 2007; Hossack et al. 2013a; Sokos et al. 2016; Dwiyahreni 2020). Because less-dense populations may offer less-frequent contact events (Sanchez and Hudgens 2015; Albery et al. 2021c), reduced density could lead to reduced transmission and maintenance of density- 
dependent pathogens (Cote and Poulin 1995; Hossack et al. 2013a). This effect could also reduce risk for interspecific transmission to humans ("spillover"). For example, Ecke et al. (2019) found that bank vole (Myodes glareolus Schreber, 1780) populations in fire-afflicted areas posed a lower spillover risk for Puumala orthohantavirus (PUUV) because there were fewer voles in these areas for humans to encounter (i.e., a lower population density). Additionally, decreased density could reduce the competition for available resources, so that the remaining individuals actually have access to more and better nutrition, which most often increases resistance (Altizer et al. 2018; Becker and Hall 2014; Becker et al. 2018).

For multi-host pathogens, direct fire-associated mortality could reduce prevalence in one fire-resistant host by killing off other vulnerable hosts involved in transmission. Many pathogens such as trematodes need intermediate hosts to complete their life cycle, and the loss of these intermediates will severely disrupt their ecology regardless of the status of the other host species. For example, fire has been wielded to intentionally disrupt the habitat of snail hosts to reduce Parelaphostrongylus tenuis Dougherty, 1945 nematode infections in ungulates without unduly affecting the ungulates themselves (Weir 2009). However, some snails are thought to be resistant to fire (Kiss and Magnin 2003, 2006), and many inhabit aquatic environments (e.g., Lymnaea Linnaeus, 1758, hosts of liver flukes; Taylor et al. 2015), which could spare them the most severe impacts of fire (Hossack et al. 2013a). As such, fire could shift the disease community from pathogens that use fire-susceptible intermediate hosts (Torre et al. 2013), including many arthropods (Bess et al. 2002; Barratt et al. 2019), towards those with resistant intermediate hosts like water snails. This process is closely linked to the idea of community alteration that we elaborate on below.

Similarly, many pathogens rely on arthropod vectors to be transmitted, and it stands to reason that the loss of these species will drive down the prevalence of the disease. Because fires can disrupt arthropod communities for years or even decades (Barratt et al. 2019), the vertebrate hosts that share pathogens with these species could enjoy an extended period of freedom from such diseases. Several studies have demonstrated that some high-intensity wildfires kill ticks in the environment (see above; reviewed in Scasta 2015), and lower contact rates with infected ticks could reduce the transmission of tick-borne pathogens; however, studies have yet to provide evidence for a link between fire and the prevalence of tick-borne pathogens (Gleim et al. 2019; Parker-Fann 2020). In contrast, evidence suggests that prescribed fires only suppress environmental ticks transiently (Padgett et al. 2009; Pascoe et al. 2020), and studies have yet to demonstrate a fire-related decrease in tick burdens on hosts themselves, despite several investigations (e.g., Pascoe et al. 2020). Additionally, some ticks can be flame resistant or at least access refugia where they can survive fire (MacDonald et al. 2018), so even providing evidence for these processes in one context may be insufficient to draw conclusions about ticks in general. As such, although there are many reasons to expect that fire will affect the epidemiology of arthropods and their diseases, the evidence is equivocal.

It is tempting to conclude, then, that direct fireassociated mortality will generally decrease the burden of disease. However, there are some mechanisms by which mortality tolls could exacerbate disease in the wake of fire. Most notably, some opportunistic parasites and pathogens can survive and proliferate in dead and decaying bodies of animals, which could increase environmental disease risk, particularly if the dead contaminate sources of drinking water. Additionally, mortality can motivate substantial behavioral responses that could exacerbate disease risk, and the loss of certain species and individuals could alter the composition of the wildlife community, with a variety of complex impacts on disease.

\section{Host movement and sociality}

Because wildfires are life-threatening and shape the environment, they can profoundly affect animal behavior (Engstrom 2010; Cohen et al. 2019; Gonino et al. 2019; Pausas 2019). Fauna in active fire zones adopt general and predictable response mechanisms to cope with wildfire-induced habitat change and destruction (Pausas 2019; Nimmo et al. 2021). These methods generally involve either moving to fire-protected microhabitats within the flame zone known as refugia, or relocating outside of the flame zone (Pausas 2019). Although these reactions to fire can help animals avoid direct mortality caused by fire, they could alter how animals meet and interact, thereby altering both intra- and interspecies contact networks, with downstream consequences for disease transmission and maintenance (Albery et al. 2021b). The frequency of these movements is generally correlated with fire frequency and severity, and regular movements can occur extremely frequently in some scenarios (Banks et al. 2011).

Fire-protected refugia include burrows, dens, trees, or other unburned "islands" (Pausas 2019; Steenvoorden et al. 2019). Although these areas might not be a preferred habitat, they constitute an important survival opportunity for fauna that have strong site fidelity or that lack the capacity to escape the flame zone (Steenvoorden et al. 2019). Refugia are also essential for post-fire repopulation; the presence of such in situ survival opportunities is a proposed determinant of abundance and 
community diversity in small mammals immediately post-fire (Banks et al. 2011). Concomitantly, refugia use can affect pathogen transmission for some hosts by heightening the chance of aggregation in unburned islands. Bank vole populations in Sweden experienced increased prevalence of PUUV following a wildfire in which individuals sought refuge in unburned areas of the forest (Ecke et al. 2019). The authors suggested that this increased prevalence may have been driven by heightened contact rates resulting from aggregation in these limited refugia (Ecke et al. 2019). It is likely that such processes could act for a range of refugia. For example, shared burrow use is thought to be an important driver of parasite transmission in animals such as desert tortoises (Gopherus agassizii Cooper, 1863; Aiello et al. 2016) and European badgers (Meles meles Linnaeus, 1758; Butler and Roper 1996), and sheltering underground in the course of a fire will likely drive greater parasite transmission in a range of animals.

Animals also respond to wildfire by fleeing the flame zone (Engstrom 2010; Pausas 2019). This strategy is common in fast-moving animals such as birds and bats (Steel et al. 2019; Mardiastuti 2020). For example, wrens (Cistothorus Cabanis, 1850 sp.), Henslow's sparrows (Centronyx henslowii Audubon, 1829), and ground parrots (Pezoporus wallicus Kerr, 1792) have been observed "outflying" approaching fires (McNair 1998). Giant anteaters (Myrmecophaga tridactyla Linnaeus, 1758) in Brazil and meadow voles (Microtus pennsylvanicus Ord, 1815) in Nebraska, USA, have likewise been shown to attempt escape from the burning area (Geluso and Bragg 1986; Silveira et al. 1999). As yet, there are no direct examples of disease consequences of fire avoidance; however, because this response involves movement outside the preferred habitat, accompanied and motivated by direct mortality, its effects could closely follow the effects of culling, which has been much studied for its disease consequences. Most notably, European badgers are often culled in the UK to prevent bovine tuberculosis (Mycobacterium bovis Karlson \& Lessel, 1970; bTB) transmission. Despite the intention of reducing disease prevalence, culling may lead to increased bTB prevalence in neighboring areas through a so-called "perturbation effect": disrupting badgers' social structure motivates them to disperse, spreading the disease farther, while concurrently reducing prevalence within the cull zone through lower badger density (Donnelly et al. 2006; Woodroffe et al. 2006; Ham et al. 2019). Similar perturbations have been observed in reindeer (Rangifer tarandus Linnaeus, 1758) culled for chronic wasting disease (Mysterud et al. 2020). Because fire provokes a similar combination of mortality within the danger area and dispersal outwards, it seems likely that fire will similarly drive the outward spread of enzootic diseases, although fire's additional effects could result in a very different overall change in disease dynamics.

\section{Host community alteration and food web disruption}

By killing animals and motivating emigration, fire often alters wildlife community composition, sometimes in ways that are complex and difficult to predict across taxa (Bess et al. 2002; Dawson et al. 2007; Steel et al. 2019; Mardiastuti 2020). Post-fire communities may be preferentially populated with species that are either fire resistant or able to disperse from nearby unburned areas (McKenzie et al. 2004; Pausas 2019; Halofsky et al. 2020). Fire also alters nutrient cycling (Gongalsky et al. 2021), which could have complex downstream effects for disease at an ecosystem level (Borer et al. 2021). Differences in community composition can be long lasting post-fire -7 to 9 years for terrestrial amphipods, for example (Barratt et al. 2019) —and so could the implications for disease.

Fire-induced changes in community composition could alter disease transmission at a population or community level: for example, if certain competent tick species (i.e., those that are able to transmit a given pathogen) survive fire more easily than non-competent ones, this may shift the ectoparasite community to favor the transmission of a range of tick-borne diseases (MacDonald et al. 2018). Fire can either decrease or increase the diversity of certain subsets of animals, or of the community as a whole (Steel et al. 2019), which could have complex effects on disease (Johnson and Thieltges 2010). Notably, the biodiversity-disease literature discusses the non-linear implications of changes in biodiversity for the transmission of a range of diseases, producing either a "dilution effect" or an "amplification effect" (e.g., Johnson and Thieltges 2010; Civitello et al. 2015; Huang et al. 2016). The dilution effect occurs when additional diversity reduces the burden of disease in a system, while the amplification effect predicts the opposite. Although these effects are sometimes contentious (Rohr et al. 2020) and scale-dependent (Halliday and Rohr 2019) and are therefore difficult to predict, it is likely that fire's community-level effects will have a substantial effect on infection dynamics that may conform to their predictions. Importantly, disruption could manifest at the within-species level as well as between species: if certain highly susceptible classes of a given host species (e.g., naive or immunocompromised individuals) are killed off by fire, this could render a pathogen unable to survive in the post-burn ecosystem because the pool of susceptible individuals may not be sufficiently large.

Predator densities can decrease with spatial or temporal proximity to some types of fires (Jorge et al. 2020), 
which could release remaining prey animals from predation pressure, allowing them to attain greater densities that are more conducive to pathogen maintenance. In other cases, shifting prey-community composition can determine predators' diets: after a wildfire in New South Wales, Australia, tiger quolls (Dasyurus maculatus Kerr, 1792) shifted to consume a greater proportion of available lagomorphs to make up for the lower abundance of possums (Trichosurus vulpecula Kerr, 1792) (Dawson et al. 2007). Such shifts could alter the transmission of pathogens with multi-stage life cycles involving consumption such as tapeworms (Cestoda).

Scavenging animals like vultures function as keystone species that reduce the burden of disease by removing decaying carcasses from the environment (Markandya et al. 2008; Buechley and Şekercioğlu 2016; Santangeli et al. 2019). If fires kill off these scavengers, such decaying organic matter may become much more common, with disease increasing as a result of greater biomass available for facultative pathogens, prolonged transmission of disease from the decaying carcasses, and increased contact among scavenging mammals (Hill et al. 2018; Ogada et al. 2012; Sage et al. 2019). For example, the loss of vultures in India has led to an increase in corpse availability for wild dogs, with a resultant increase in rabies rates (Markandya et al. 2008). Wildfires have been identified as an important contributing factor to the decline of the California condor, Gymnogyps californianus Shaw, 1797 (Kelly et al. 2015), so similar eventualities may apply to the recent fires in the area. Alternatively, predators that do remain in the environment might be able to take advantage of greater quantities of fire-associated carrion, particularly if compensating for fewer prey animals (Dawson et al. 2007). Species that are adapted to eating carrion often have a suite of immunological and physiological characteristics that allow them to consume rotting flesh while minimizing the risk of infection (Blumstein et al. 2017), so switching to facultative scavenging may be associated with a greater disease risk for these opportunistic species (rather than scavengingspecialized species; Vicente and VerCauteren 2019).

\section{Stress, injury, and condition}

The process of being threatened and having to move due to fire can be stressful for wild animals (Collins and Wallace, 1990), while fire and exposure to smoke can directly injure them (Erb et al. 2018; Joordaan et al. 2019; Harris et al. 2020), all of which could have downstream effects on their health. Generalized "stress" is often theorized to decrease immune resistance (Romero 2004; Martin 2009; Hing et al. 2016), and although this effect is not always observed (Romeo et al. 2020), it is possible that stressed animals in the wake of fire will be in worse condition and have weaker immunity, leading to greater pathogen prevalence. These trends will be species and context dependent: for example, a study in Australian woylie (Bettongia penicillata Gray, 1837) found no evidence for altered fecal cortisol metabolites (indicative of stress) or parasite burdens in the aftermath of fire (Hing et al. 2017). Box turtles (Terrapene carolina Linnaeus, 1758) do not alter movement in response to fire because of their limited dispersal ability and the protection afforded by their shells; however, they received direct fire-induced injuries and were less likely to survive in a burned year (Harris et al. 2020). Infections associated with burn damage to the carapace could have contributed to this mortality. When considering stressrelated impacts, it is important to remember that stress and condition are often indicative of (or predictive of) immunity, but they are not identical ( Romero 2004; Martin 2009; Hing et al. 2016; Sánchez et al. 2018). Changes in stress (or stress indicators) will not necessarily mean a downstream impact on immunity, and any changes in immunity also may not translate to changes in disease. However, fire will directly affect immunity through pyrogenic immune agonists produced by chemical reactions.

\section{Pollution and water quality}

Fire is a powerful agent of chemical change that can create a substantial shift in an ecosystem's elemental composition. This shift includes an increase in a variety of harmful toxicants and pollutants both in the air and soil, including cyanide and other toxins, heavy metals, and harmful hydrocarbons (Brunke et al. 2001; Kelly et al. 2006; Urbanski et al. 2008; Burke et al. 2013; Guo et al. 2020). Based on laboratory exposure studies and ecological studies of anthropogenic pollution events such as oil spills, exposure to such contaminants is likely to result in dysregulation of the immune response, which could harm animals' resistance to pathogens, producing greater disease burdens (Becker et al. 2020). In partial support of this prediction, a study of Californian sea otters' (Enhydra lutris Linnaeus, 1758) transcriptomes found that wildfires altered the expression of a range of genes associated with detoxifying polycyclic aromatic hydrocarbons (PAH), representing a substantial shift in their immune states (Bowen et al. 2015).

Fire also affects water quality by altering light, nutrients, and $\mathrm{pH}$ levels and can undermine ecosystem functions that affect water bodies, such as filtration (Hahn et al. 2019; McCullough et al. 2019). These changes can then affect fish (e.g., altering their behavior; Gonino et al. 2019). Notably, fires can drive a release of mercury from soil that then contaminates lakes and the fish inhabiting them (McCullough et al. 2019). Terrestrial consumers in turn become exposed to mercury by feeding on aquatic food sources, and this contaminant can have 
substantial immunosuppressive effects (Becker et al. 2017, Becker et al. 2021). It stands to reason that fireassociated mercury leaching could have far-reaching effects on the immune landscape of an ecosystem that could increase susceptibility to disease, exacerbating prevalence even in the long term. Although waterdwelling animal species may be spared the stress, injury, and movement-specific costs of fire, they will likely suffer in the aftermath due to these aquatic effects, accentuating the potentially wide-reaching impacts of fire on disease.

There is no fire without smoke, and the immunological impacts of smoke inhalation are well understood in humans and animals. For example, smoke is thought to provoke harmful autoimmune responses in humans (Perricone et al. 2016), and macaques (Macaca mulatta Zimmermann, 1780) have been used to study smokeassociated immune dysregulation (Black et al. 2017). Smoke exposure in orangutans (Pongo Lacépède, 1799 sp.) is energetically costly and results in reduced condition, possibly because smoke stimulates immunity (Erb et al. 2018), and Australian bushfires resulted in substantial pulmonary pathology and mortality in smoky mice (Pseudomys fumeus Brazenor, 1934; Peters et al. 2020). Fundamentally, the immune response is costly in terms of resources and energy, and therefore, any stimulation of an immune response by a foreign agonist can result in reduced fitness, regardless of any infections (Graham et al. 2010, Graham et al. 2011). As such, fire's chemical effects could have negative repercussions for the immune system, driving increased disease and ultimately threatening the viability of a fire-stricken wildlife population.

\section{Future directions}

\section{Study systems and methodological opportunities}

There exists some literature on wildfires and wildlife disease, much of which we have cited above. However, many of the links that we hypothesize remain uninvestigated and unevidenced; addressing these gaps will require a range of empirical systems merging fire and disease studies, which can be difficult due to the unpredictable and often catastrophic nature of wildfire events. A good number of fire-disease studies made use of "natural experiments" emerging from studies of natural populations pre-, during, and post-fire (Fuentes et al. 2010; Hossack et al. 2013a; Pascoe et al. 2020), but these events may be impossible to anticipate and prepare for given their inherently unpredictable nature. Prescribed fires are likewise often used to examine the effect of fire on environmental parasite distributions (Scasta 2015), and they could be used in experimental contexts to test the hypotheses that we put forward here: for example, by comparing observed pathogen burdens before and after a prescribed burn, or in managed versus unmanaged areas. However, prescribed fires and wildfires are not equivalent and deserve their own research agendas (Hiers et al. 2020; Hunter and Robles 2020), so these experiments should be applied carefully.

Because fire is difficult to study, some similar ecological processes can be used to approximate specific effects in isolation, which could then contribute to supporting our synthetic framework (Fig. 1). For example, lessons from oil spills and related chemical disasters could be used to inform pyrogenic pollutants' effects on animal immune systems (e.g., Bowen et al. 2015), without the confounding effects of changes in movement or population dynamics. Human-instigated culling regimes could inform how animals' flight responses and large-scale movements affect the spread of disease in wildfires (Donnelly et al. 2006; Ham et al. 2019; Mysterud et al. 2020). The same is true of a range of human activities, such as logging (Fisher and Wilkinson 2005). Importantly, there has been a substantial focus on fire-related studies published in the USA (and recently in Australia; Dennison et al. 2014; Ward et al. 2020). This bias mirrors the skew in disease surveillance toward developed countries over the developing world (Allen et al. 2017; Carlson et al. 2020b). In the future, strengthening tropical forest fire surveillance (Mardiastuti 2020) alongside disease surveillance will be important to ensure an equitable understanding of the impact of these global stressors.

To draw effective conclusions about the behavioral impacts of fire on disease, future studies should build on the rise of telemetry, biologging, and network science in ecology (Kays et al. 2015; Smith and Pinter-Wollman 2020; Williams et al. 2020) and their increasing integration with disease ecology (Dougherty et al. 2018; Silk et al. 2019; Albery et al. 2021b). Fire-related movement and occupancy models that are relatively common, particularly in birds (Russell et al. 2009; Cohen et al. 2019; Steenvoorden et al. 2019; Stillman et al. 2019; Wan et al., 2020) and bats (Steel et al. 2019), could be integrated with disease-related movement models, contact processes, and social network analyses (Dougherty et al. 2018; White et al. 2018; Albery et al. 2021b), to identify how fire-related changes in behavior and demography could alter pathogen transmission and emergent epidemiological consequences while accounting for sampling effort and observation error.

\section{Open questions}

Moving forward, a broader set of studies linking fire and wildlife disease will allow us to predict the impacts of fire on host-pathogen systems. Beyond the first-order associations that we list in our framework, we discuss a few broad areas that will benefit from explicit 
consideration, including context dependence, timescale, sampling effects, implications for spillover, and comparison to other natural disasters.

Fire-disease interactions are likely highly context dependent and often non-linear in ways that we can only begin to appreciate with the data available. For example, as noted above, pathogen responses to fire will be dependent on transmission mode (Hossack et al. 2013a). The predictions will also depend on a wide range of fire traits such as size, intensity, duration, and burn heterogeneity. The effects of mortality on disease will depend on the proportion of the population killed, the biomass and the species involved, and the history of fire in the focal ecosystem: species inhabiting fire-prone ecosystems have often evolved tolerance mechanisms to regular low-level fires, but this may vary from species to species (Buchholz et al. 2019). For all these reasons, a prominent open question is how a given fire regime (and changes to the regime brought about by global change) will determine disease dynamics. Finally, the conclusions drawn will depend on the study's spatiotemporal scale. Scales of study are important in fire ecology (Hunter and Robles 2020; Wan et al. 2020), as they are in disease ecology (Gilligan et al. 2007; Halliday and Rohr 2019), and considering the resolution for both aspects may be doubly important.

The timescale of the investigation is an especially important contextual factor to consider. It is intuitive that the effects of fire will not be homogenous through time, so its observed effects on disease will depend on the time point at which it was investigated. For example, large ungulates tend to leave the burning area but swiftly recolonize it after the blaze has stopped to take advantage of sapling regrowth (Fisher and Wilkinson 2005; Davies and Boyd 2019; Herkenrath 2019). During and immediately following fire, animals' necessity to use suboptimal habitats could reduce their condition (Baranowski et al. 2020), as could the stress of evacuation, while their aggregation in potentially small islands of suitable habitat could increase contact rates (Ecke et al. 2019). All of these processes could cause disease burdens to grow rapidly in the short term. In the aftermath of fire, the recolonization of a burned area and likely reduced host density (Fisher and Wilkinson 2005; Sokos et al. 2016) could afford animals food of a higher quality or quantity, conferring improved condition, stronger immune responses, and reduced burdens of disease. Over time, as the ecosystem recovers, the host population will likely restabilize at carrying capacity (Sokos et al. 2016), increasing transmission of densitydependent pathogens. These factors will similarly depend fundamentally on fire regimes, which differ in fire size, frequency, intensity, season, and extent (Archibald et al. 2013).
Importantly, although wildfires are often painted as catastrophic, destructive events-and they may be increasingly so under climate change (Higuera and Abatzoglou 2021) -fire is also a natural component of a great many ecosystems, managing turnover of vegetation and providing crucial habitat for a range of fire-adapted species (Pausas 2019; Nimmo et al. 2021). Fire shares many functional similarities with herbivores (Bond and Keeley 2005), and just as some pathogens have evolved to transmit through herbivore ingestion, there may be parasites whose life cycles depend on flames, either directly or indirectly, to develop and achieve onward transmission. Similarly, while we suggested above that parasite community disruption could lead to destabilization and increased spillover, parasite communities in fire-prone areas may be more resilient to fire-related disturbances in ways that reduce this risk. Additionally, fires are highly seasonal, generally occurring in drier periods (Miller et al. 2020). Many infectious diseases are also seasonal (Altizer et al. 2006), and it is possible that fluctuating fire regimes play a role in driving this seasonality; therefore, altered fire phenology in the future could alter these patterns.

To address these questions and to overcome these sampling challenges, researchers in fire and disease ecology may benefit from succession-like sampling regimes, incorporating sampling "before, shortly following, and long after" fire (Hing et al. 2017), "before, during, and after" (Erb et al. 2018), or (ideally) regularly and longitudinally throughout burn events (Sokos et al. 2016; Jones et al. 2018; MacDonald et al. 2018). These may be accompanied by paired spatial designs of "control" versus "burn" areas (e.g., Fuentes et al. 2010; Pascoe et al. 2020). Unfortunately, mortality could leave small sample sizes available shortly following fire, making it difficult to detect disease effects (Jones et al. 2018). Researchers should bear in mind the life cycle of the parasite and its generation time. For example, effects on individual burdens of soil-transmitted helminths may be difficult to detect in the days and weeks following the fire because helminths can take months to complete their life cycle. In contrast, respiratory pathogens with short life cycles may exhibit an immediate peak facilitated by increased contact rates in the wake of fire (Ecke et al. 2019). Mardiastuti (2020) notes that the observed effects of fire on birds depend on the stage at which they are examined. During the fire, some birds will benefit (e.g., raptors will gain increased access to panicked prey such as small mammals on the forest floor or insects in rising smoke columns). After fire, the abundance of different species will be dependent on their remaining habitat and the time since burning. Community changes in the wake of fire can be complex and non-monotonic (e.g., as in ant 
communities; Gosper et al. 2015) and may need highly replicated, high-intensity sampling to be understood.

Finally, because most emerging human diseases originate in wild animals (Woolhouse 2006; Jones et al. 2008; Morse et al. 2012), it is crucial that we understand how fires could alter spillover of pathogens into human populations. Indeed, several fire studies have mentioned or examined spillover explicitly (e.g., Ecke et al. 2019; Baranowski et al. 2020; Parker-Fann 2020), indicating that this is already a concern for ecologists working in the area. Predictions for spillover are likely to be even more complicated than inference about wildlife disease itself and must be considered in the light of both hazard and risk for human populations. For example, although voles had a higher prevalence of Puumala hantavirus post-fire, the concurrent reduced vole population density actually reduced the probability that a human would encounter an infected vole, lowering risk overall (Ecke et al. 2019); similarly, Parker-Fann (2020) reported no difference in Lyme disease prevalence in animal reservoirs post-fire, but fewer competent hosts produced lower overall spillover risk. Combining future fire-disease studies with measures of human population density and wildlife encounter probability, and then designing interventions to reduce spillover risk, will be important next steps.

\section{Concluding remarks}

The Anthropocene is bringing with it a series of ecological challenges that are likely to interact, rather than happening in isolation. Already, links between climate change, land conversion, and population growth have driven the emergence and exacerbation of wildlife diseases (Cohen et al. 2020; Gibb et al. 2020), and these processes are only likely to accelerate and interact in the coming century (Carlson et al. 2020a; Phillips et al. 2020). Here, we have detailed potential avenues for epidemiological consequences of just one climateassociated hazard in wildlife, but similar effects may emerge for a range of large-scale disturbance events including floods, hurricanes, wars, and more. For example, if animals flee from floods in the same way that they do fires, our predictions for the exacerbating effects outlined in the "movement and sociality" section will likely hold, but its effects on environmental stages of parasites could be very different-at least for different parasites. Already, the literature presents some evidence that fire's effects are difficult to extricate from those of other extreme disturbances or weather events-most notably droughts (Pascoe et al. 2020). Investigating how these and other disruptive events are altering the face of wildlife disease, together and in isolation, will be vital for conservation and public health in an increasingly interconnected world.
Acknowledgements

We thank Daniel Becker for his helpful comments.

Authors' contributions

GFA conceived of and wrote the paper and supervised IT. IT conducted primary literature reviews and wrote excerpts of the paper. SB offered guidance. All authors gave comments and edits on the manuscript throughout. The authors read and approved the final manuscript.

\section{Funding}

GFA and SB were supported by NSF grant no. 1414296 as part of the joint NSF-NIH-USDA Ecology and Evolution of Infectious Diseases program. JEF acknowledges funding support from the Pacific Southwest Regional Center of Excellence for Vector-Borne Diseases funded by the US Centers for Disease Control and Prevention (Cooperative Agreement 1U01CK000516).

Availability of data and materials

This review contains no data.

\section{Declarations}

Ethics approval and consent to participate

None necessary.

Consent for publication

Not applicable.

\section{Competing interests}

The authors declare that they have no competing interests.

\section{Author details}

${ }^{1}$ Department of Biology, Regents Hall, Georgetown University, 37th and O Streets NW, Washington, DC 20057-1229, USA. ${ }^{2}$ Earth Lab, Cooperative Institute for Research in Environmental Science, University of Colorado, 4001 Discovery Drive, Suite S348 611 UCB, Boulder, CO 80303, USA. ${ }^{3}$ School of Veterinary Medicine, Department of Medicine and Epidemiology, University of California, 1 Shields Avenue, Davis, CA 95616, USA. ${ }^{4}$ School of Science, Technology and Engineering, The University of the Sunshine Coast, Sippy Downs, Queensland 4556, Australia.

Received: 24 February 2021 Accepted: 9 June 2021

Published online: 23 September 2021

\section{References}

Aiello, C.M., K.E. Nussear, T.C. Esque, P.G. Emblidge, P. Sah, S. Bansal, and P.J. Hudson. 2016. Host contact and shedding patterns clarify variation in pathogen exposure and transmission in threatened tortoise Gopherus agassizii: implications for disease modelling and management. Journal of Animal Ecology 85 (3): 829-842. https://doi.org/10.1111/1365-2656.12511.

Albery, G.F., C.J. Carlson, L.E. Cohen, E.A. Eskew, R. Gibb, S.J. Ryan, A.R. Sweeny, and D.J. Becker. 2021a. Urban-adapted mammal species have more known pathogens. BioRxiv 2021. https://doi.org/10.1101/2021.01.02.425084.

Albery, G.F., L. Kirkpatrick, J.A. Firth, and S. Bansal. 2021b. Unifying spatial and social network analysis in disease ecology. Journal of Animal Ecology 90 (1): 45-61. https://doi.org/10.1111/1365-2656.13356.

Albery, G.F., A. Morris, S. Morris, J.M. Pemberton, T.H. Clutton-Brock, D.H. Nussey, and J.A. Firth. 2021c. Multiple spatial behaviours govern social network positions in a wild ungulate. Ecology Letters 24 (4): 676-686. https://doi.org/1 0.1111 /ele.13684.

Allen, T., K.A. Murray, C. Zambrana-Torrelio, S.S. Morse, C. Rondinini, M. Di Marco, N. Breit, K.J. Olival, and P. Daszak. 2017. Global hotspots and correlates of emerging zoonotic diseases. Nature Communications 8 (1): 1124. https://doi. org/10.1038/s41467-017-00923-8.

Altizer, S., D.J. Becker, J.H. Epstein, K.M. Forbes, T.R. Gillespie, R.J. Hall, D.M. Hawley, S.M. Hernandez, L.B. Martin, R.K. Plowright, D.A. Satterfield, and D.G. Streicker. 2018. Food for contagion: synthesis and future directions for studying hostparasite responses to resource shifts in anthropogenic environments. Philosophical Transactions of the Royal Society B: Biological Sciences 373 (1745): 20170102. https://doi.org/10.1098/rstb.2017.0102. 
Altizer, S., A. Dobson, P. Hosseini, P. Hudson, M. Pascual, and P. Rohani. 2006 Apr. Seasonality and the dynamics of infectious diseases. Ecology Letters 9 (4): 467-84. https://doi.org/10.1111/j.1461-0248.2005.00879.x PMID: 16623732.

Archibald, S., C.E.R. Lehmann, J.L. Gómez-Dans, and R.A. Bradstock. 2013. Defining pyromes and global syndromes of fire regimes. Proceedings of the National Academy of Sciences 110 (16): 6442-6447. https://doi.org/10.1073/pnas.12114 66110

Balch, J.K., B.A. Bradley, J.T. Abatzoglou, R.C. Nagy, E.J. Fusco, and A.L. Mahood. 2017. Human-started wildfires expand the fire niche across the United States. Proceedings of the National Academy of Sciences 114 (11): 2946-2951. https:// doi.org/10.1073/pnas.1617394114.

Banks, S.C., M. Dujardin, L. McBurney, D. Blair, M. Barker, and D.B. Lindenmayer. 2011. Starting points for small mammal population recovery after wildfire: recolonisation or residual populations? Oikos 120 (1): 26-37. https://doi.org/1 0.1111/j.1600-0706.2010.18765.x.

Baranowski, K., C. Faust, P. Eby, and N. Bharti. 2020. Quantifying the impact of severe bushfires on biodiversity to inform conservation. Global Ecology and Conservation 27: e01566. https://doi.org/10.1016/j.gecco.2021.e01566.

Barratt, B.I.P., J.M. Wing, O.J.-P. Ball, P.D. Johnstone, and K.J.M. Dickinson. 2019. The effect of fire on terrestrial amphipods (Crustacea: Amphipoda) in a natural grassland community. Pedobiologia 77: 150590. https://doi.org/10.1016/j. pedobi.2019.150590.

Becker, D.J., G.F. Albery, M.K. Kessler, T.J. Lunn, and C,A. Falvo, G.A. Czirják, L.B. Martin, and R.K. Plowright. 2020. Macroimmunology: the drivers and consequences of spatial patterns in wildlife immune defense. Journal of Animal Ecology 89 (4): 972-995. https://doi.org/10.1111/1365-2656.13166.

Becker, D.J., M.M. Chumchal, A.B. Bentz, S.G. Platt, G.A. Czirják, T.R. Rainwater, S. Altizer, and D.G. Streicker. 2017. Predictors and immunological correlates of sublethal mercury exposure in vampire bats. Royal Society Open Science 4 (4): 170073. https://doi.org/10.1098/rsos.170073.

Becker, D.J., and R.J. Hall. 2014. Too much of a good thing: resource provisioning alters infectious disease dynamics in wildlife. Biology Letters 10 (7): 20140309 20140309. https://doi.org/10.1098/rsbl.2014.0309.

Becker, D.J., R.J. Hall, K.M. Forbes, R.K. Plowright, and S. Altizer. 2018. Anthropogenic resource subsidies and host-parasite dynamics in wildlife. Philosophical Transactions of the Royal Society B: Biological Sciences 373 (1745): 20170086. https://doi.org/10.1098/rstb.2017.0086.

Becker, D.J., K.A. Speer, J.M. Korstian, D.V. Volokhov, H.F. Droke, A.M. Brown, C.L. Baijnauth, T. Padgett-Stewart, H.G. Broders, R.K. Plowright, T.R. Rainwater, M.B. Fenton, N.B. Simmons, and M.M. Chumchal. 2021. Disentangling interactions among mercury, immunity and infection in a Neotropical bat community. Journal of Applied Ecology 58 (4): 879-889. https://doi.org/10.1111/1365-2 664.13809.

Bess, E.C., R.R. Parmenter, S. McCoy, and M.C. Molles. 2002. Responses of a riparian forest-floor arthropod community to wildfire in the Middle Rio Grande Valley, New Mexico. Environmental Entomology 31 (5): 774-784. https://doi.org/10.1 603/0046-225X-31.5.774

Black, C., J.E. Gerriets, J.H. Fontaine, R.W. Harper, N.J. Kenyon, F. Tablin, E.S. Schelegle, and L.A. Miller. 2017. Early life wildfire smoke exposure is associated with immune dysregulation and lung function decrements in adolescence. American Journal of Respiratory Cell and Molecular Biology 56 (5): 657-666. https://doi.org/10.1165/rcmb.2016-03800C

Block, W.M., L.M. Conner, P.A. Brewer, P. Ford, J. Haufler, A. Litt, R.E. Masters, L.R. Mitchell, and J. Park. 2016. Effects of prescribed fire on wildlife and wildlife habitat in selected ecosystems of North America. In The Wildlife Society Technical Review 16(01). Bethesda: The Wildlife Society https://wildlife.org/wpcontent/uploads/2014/05/TechManual16-01FINAL.pdf.

Blumstein, D.T., T.N. Rangchi, T. Briggs, F.S. De Andrade, and B. NattersonHorowitz. 2017. A systematic review of carrion eaters' adaptations to avoid sickness. Journal of Wildlife Diseases 53 (3): 577-581. https://doi.org/10.7589/2 016-07-162.

Bond, W.J., and J.E. Keeley. 2005. Fire as a global 'herbivore': the ecology and evolution of flammable ecosystems. Trends in Ecology \& Evolution 20 (7): $387-$ 394. https://doi.org/10.1016/j.tree.2005.04.025.

Borer, E.T., L. Asik, R.A. Everett, T. Frenken, A.L. Gonzalez, R.E. Paseka, A. Peace, E.W. Seabloom, A.T. Strauss, D.B.V. de Waal, and L.A. White. 2021. Elements of disease in a changing world: modelling feedbacks between infectious disease and ecosystems. Ecology Letters 24 (1): 6-19. https://doi.org/10.1111/ ele.13617.

Bowen, L., A.K. Miles, C.A. Kolden, J.A. Saarinen, J.L. Bodkin, M.J. Murray, and M.T. Tinker. 2015. Effects of wildfire on sea otter (Enhydra lutris) gene transcript profiles. Marine Mammal Science 31 (1): 191-210. https://doi.org/10.1111/ mms.12151.

Brunke, E.-G., C. Labuschagne, and F. Slemr. 2001. Gaseous mercury emissions from a fire in the Cape Peninsula, South Africa, during January 2000. Geophysical Research Letters 28 (8): 1483-1486. https://doi.org/10.1029/2 000GL012193.

Buchholz, R., J.D. Banusiewicz, S. Burgess, S. Crocker-Buta, L. Eveland, and L. Fuller. 2019. Behavioural research priorities for the study of animal response to climate change. Animal Behaviour 150: 127-137. https://doi.org/10.1016/j.a nbehav.2019.02.005.

Budischak, S.A., A.E. Wiria, F. Hamid, L.J. Wammes, M.M.M. Kaisar, L. van Lieshout, E. Sartono, T. Supali, M. Yazdanbakhsh, and A.L. Graham. 2018. Competing for blood: the ecology of parasite resource competition in human malariahelminth co-infections. Ecology Letters 21 (4): 536-545. https://doi.org/1 0.1111/ele.12919.

Buechley, E.R., and Ç.H. Şekercioğlu. 2016. The avian scavenger crisis: looming extinctions, trophic cascades, and loss of critical ecosystem functions. Biological Conservation 198: 220-228. https://doi.org/10.1016/j.biocon.2016.04.001.

Burke, M.P., T.S. Hogue, A.M. Kinoshita, J. Barco, C. Wessel, and E.D. Stein. 2013. Pre- and post-fire pollutant loads in an urban fringe watershed in Southern California. Environmental Monitoring and Assessment 185 (12): 10131-10145. https://doi.org/10.1007/s10661-013-3318-9.

Butler, J.M., and T.J. Roper. 1996. Ectoparasites and sett use in European badgers. Animal Behaviour 52 (3): 621-629. https://doi.org/10.1006/anbe.1996.0203.

Carlson, C.J., G.F. Albery, C. Merow, C.H. Trisos, C.M. Zipfel, E.A. Eskew, K.J. Olival, N. Ross, and S. Bansal. 2020a. Climate change will drive novel cross-species viral transmission. BioRxiv 2020 (01): 24.918755. https://doi.org/10.1101/2020.01.24. 918755.

Carlson, C.J., K.R. Burgio, E.R. Dougherty, A.J. Phillips, V.M. Bueno, C.F. Clements, G. Castaldo, T.A. Dallas, C.A. Cizauskas, G.S. Cumming, J. Doña, N.C. Harris, R. Jovani, S. Mironov, O.C. Muellerklein, H.C. Proctor, and W.M. Getz. 2017. Parasite biodiversity faces extinction and redistribution in a changing climate. Science Advances 3 (9): e1602422. https://doi.org/10.1126/sciadv.1602422.

Carlson, C.J., T.A. Dallas, L.W. Alexander, A.L. Phelan, and A.J. Phillips. 2020b. What would it take to describe the global diversity of parasites? Proceedings of the Royal Society B: Biological Sciences 287 (1939): 20201841. https://doi.org/10.1 098/rspb.2020.1841

Civitello, D.J., J. Cohen, H. Fatima, N.T. Halstead, J. Liriano, T.A. McMahon, C.N. Ortega, E.L. Sauer, T. Sehgal, S. Young, and J.R. Rohr. 2015. Biodiversity inhibits parasites: broad evidence for the dilution effect. Proceedings of the National Academy of Sciences 112 (28): 8667-8671. https://doi.org/10.1073/ pnas.1506279112.

Cohen, B.S., T.J. Prebyl, B.A. Collier, and M.J. Chamberlain. 2019. Spatiotemporal variability of fire characteristics affect animal responses in pyric landscapes. Fire Ecology 15 (1): 41. https://doi.org/10.1186/s42408-019-0058-4.

Cohen, J.M., S.L. Sauer, O. Santiago, S. Spencer, and J.R. Rohr. 2020. Divergent impacts of warming weather on wildlife disease risk across climates. Science 370 (6519): eabb1702. https://doi.org/10.1126/science.abb1702.

Collins, S.L., and L.L. Wallace, eds. 1990. Fire in North American tallgrass prairies. American Institute of Biological Sciences, Ecological Society of America, and Botanical Society of America. Norman: University of Oklahoma Press.

Cote, I.M., and R. Poulin. 1995. Parasitism and group size in social animals: a meta-analysis. Behavioral Ecology 6 (2): 159-165. https://doi.org/10.1093/ beheco/6.2.159.

Davies, K.W., and C.S. Boyd. 2019. Ecological effects of free-roaming horses in North American rangelands. BioScience 69 (7): 558-565. https://doi.org/10.1 093/biosci/biz060.

Dawson, J.P., A.W. Claridge, B. Triggs, and D.J. Paull. 2007. Diet of a native carnivore, the spotted-tailed quoll (Dasyurus maculatus): before and after an intense wildfire. Wildlife Research 34 (5): 342-351. https://doi.org/10.1071/WR05101.

Dennison, P.E., S.C. Brewer, J.D. Arnold, and M.A. Moritz. 2014. Large wildfire trends in the western United States, 1984-2011. Geophysical Research Letters 41 (8): 2928-2933. https://doi.org/10.1002/2014GL059576.

Donnelly, C.A., R. Woodroffe, D.R. Cox, F.J. Bourne, C.L. Cheeseman, R.S. CliftonHadley, G. Wei, G. Gettinby, P. Gilks, H. Jenkins, W.T. Johnston, A.M. Le Fevre, J.P. Mclnerney, and W.I. Morrison. 2006. Positive and negative effects of widespread badger culling on tuberculosis in cattle. Nature 439 (7078): 843846. https://doi.org/10.1038/nature04454.

Dougherty, E.R., D.P. Seidel, C.J. Carlson, O. Spiegel, and W.M. Getz. 2018. Going through the motions: incorporating movement analyses into disease research. Ecology Letters 21 (4): 588-604. https://doi.org/10.1111/ele.12917. 
Dwiyahreni, A.A. 2020. The effect of forest fire on the squirrel and tree shrew community dynamic in Southern Sumatra. IOP Conference Series: Earth and Environmental Science 481: 012004. https://doi.org/10.1088/1755-1315/481/1/ 012004.

Ecke, F., S.A.N. Mahani, M. Evander, B. Hörnfeldt, and H. Khalil. 2019. Wildfireinduced short-term changes in a small mammal community increase prevalence of a zoonotic pathogen? Ecology and Evolution 9 (22): 12459 12470. https://doi.org/10.1002/ece3.5688.

Engstrom, R.T. 2010. First-order fire effects on animals: review and recommendations. Fire Ecology 6 (1): 115-130. https://doi.org/10.4996/fireecology.0601115.

Erb, W.M., E.J. Barrow, A.N. Hofner, S.S. Utami-Atmoko, and E.R. Vogel. 2018. Wildfire smoke impacts activity and energetics of wild Bornean orangutans. Scientific Reports 8 (1): 7606. https://doi.org/10.1038/s41598018-25847-1.

Erwin, W.J., and R.H. Stasiak. 1979. Vertebrate mortality during the burning of a reestablished prairie in Nebraska. The American Midland Naturalist 101 (1): 247-249. https://doi.org/10.2307/2424922.

Fagre, A., L.E. Cohen, E.A. Eskew, M. Farrell, E. Glennon, M.B. Joseph, H.K. Frank, S Ryan, C.J. Carlson, and G. Albery. 2021. Spillback in the Anthropocene: the risk of human-to-wildlife pathogen transmission for conservation and public health. EcoEvoRxiv. https://doi.org/10.32942/osf.io/sx6p8.

Fisher, J.T., and L. Wilkinson. 2005. The response of mammals to forest fire and timber harvest in the North American boreal forest. Mammal Review 35 (1): 51-81. https://doi.org/10.1111/j.1365-2907.2005.00053.x.

Fuentes, M.V., S. Sainz-Elipe, S. Sáez-Durán, and M.T. Galán-Puchades. 2010. The helminth community of the wood mouse Apodemus sylvaticus in a Mediterranean ecosystem in regeneration ten years after a wildfire. Journal of Helminthology 84 (1): 39-48. https://doi.org/10.1017/S0022149X09990277.

Geluso, K.N., and T.B. Bragg. 1986. Fire-avoidance behavior of meadow voles (Microtus pennsylvanicus). The American Midland Naturalist 116 (1): 202-205. https://doi.org/10.2307/2425953.

Gibb, R., D.W. Redding, K.Q. Chin, C.A. Donnelly, T.M. Blackburn, T. Newbold, and K.E. Jones. 2020. Zoonotic host diversity increases in human-dominated ecosystems. Nature 584 (7821): 398-402. https://doi.org/10.1038/s41586-020-2 $562-8$.

Gibbs, E.P.J. 2014. The evolution of One Health: a decade of progress and challenges for the future. Veterinary Record 174 (4): 85-91. https://doi.org/1 0.1136/vr.g143.

Gilligan, C.A., J.E. Truscott, and A.J. Stacey. 2007. Impact of scale on the effectiveness of disease control strategies for epidemics with cryptic infection in a dynamical landscape: an example for a crop disease. Journal of The Royal Society Interface 4 (16): 925-934. https://doi.org/10.1098/rsif.2007.1019.

Gleim, E.R., G.E. Zemtsova, R.D. Berghaus, M.L. Levin, M. Conner, and M.J. Yabsley. 2019. Frequent prescribed fires can reduce risk of tick-borne diseases. Scientific Reports 9 (1): 9974. https://doi.org/10.1038/s41598-019-46377-4.

Gongalsky, K.B., A.S. Zaitsev, D.I. Korobushkin, R.A. Saifutdinov, K.O. Butenko, F.T. de Vries, K. Ekschmitt, M.I. Degtyarev, A.Y. Gorbunova, N.V. Kostina, A. A. Rakhleeva, S.B. Shakhab, T.E. Yazrikova, V. Wolters, and R.D. Bardgett. 2021. Forest fire induces short-term shifts in soil food webs with consequences for carbon cycling. Ecology Letters 24 (3): 438-450. https:// doi.org/10.1111/ele.13657.

Gonino, G., P. Branco, E. Benedito, M.T. Ferreira, and J.M. Santos. 2019. Short-term effects of wildfire ash exposure on behaviour and hepatosomatic condition of a potamodromous cyprinid fish, the Iberian barbel Luciobarbus bocagei (Steindachner, 1864). The Science of the Total Environment 665: 226-234. https://doi.org/10.1016/j.scitotenv.2019.02.108.

Gosper, C.R., M.J. Pettit, A.N. Andersen, C.J. Yates, and S.M. Prober. 2015. Multicentury dynamics of ant communities following fire in Mediterraneanclimate woodlands: are changes congruent with vegetation succession? Forest Ecology and Management 342: 30-38. https://doi.org/10.1016/j.foreco.2 015.01.006.

Graham, A.L., A.D. Hayward, K.A. Watt, J.G. Pilkington, J.M. Pemberton, and D.H. Nussey. 2010. Fitness correlates of heritable variation in antibody responsiveness in a wild mammal. Science 330 (6004): 662-665. https://doi. org/10.1126/science.1194878.

Graham, A.L., D.M. Shuker, L.C. Pollitt, S.K.J.R. Auld, A.J. Wilson, and T.J. Little. 2011 Fitness consequences of immune responses: strengthening the empirical framework for ecoimmunology. Functional Ecology 25 (1): 5-17. https://doi. org/10.1111/j.1365-2435.2010.01777.x.

Guo, L., Y. Ma, M. Tigabu, X. Guo, W. Zheng, and F. Guo. 2020. Emission of atmospheric pollutants during forest fire in boreal region of China.
Environmental Pollution 264: 114709. https://doi.org/10.1016/j.envpol.202 0.114709 .

Hahn, G.E., T.A. Coates, R.E. Latham, and H. Majidzadeh. 2019. Prescribed fire effects on water quality and freshwater ecosystems in moist-temperate eastern North America. Natural Areas Journal 39 (1): 46-57. https://doi.org/1 0.3375/043.039.0104.

Halliday, F.W., and J.R. Rohr. 2019. Measuring the shape of the biodiversitydisease relationship across systems reveals new findings and key gaps. Nature Communications 10 (1): 5032. https://doi.org/10.1038/s41467-01 9-13049-w.

Halofsky, J.E., D.L. Peterson, and B.J. Harvey. 2020. Changing wildfire, changing forests: the effects of climate change on fire regimes and vegetation in the Pacific Northwest, USA. Fire Ecology 16 (1): 4. https://doi.org/10.1186/s42408019-0062-8.

Ham, C., C.A. Donnelly, K.L. Astley, S.Y.B. Jackson, and R. Woodroffe. 2019. Effect of culling on individual badger Meles meles behaviour: potential implications for bovine tuberculosis transmission. Journal of Applied Ecology 56 (11): 2390 2399. https://doi.org/10.1111/1365-2664.13512.

Harris, K.A., J.D. Clark, R.D. Elmore, and C.A. Harper. 2020. Direct and indirect effects of fire on eastern box turtles. The Journal of Wildlife Management 84 (7): 1384-1395. https://doi.org/10.1002/jwmg.21920.

Herkenrath, T. 2019. How does white rhino respond to fires during dry season? [Second cycle, A2E]. SLU, Dept. of Wildlife, Fish and Environmental Studies. https://stud.epsilon.slu.se/14487/

Hiers, J.K., J.J. O'Brien, J.M. Varner, B.W. Butler, M. Dickinson, J. Furman, M. Gallagher, D. Godwin, S.L. Goodrick, S.M. Hood, A. Hudak, L.N. Kobziar, L.R. Linn, E.L. Loudermilk, S. McCaffrey, K. Robertson, E.M. Rowell, N. Skowronski, A.C. Watts, and K.M. Yedinak. 2020. Prescribed fire science: the case for a refined research agenda. Fire Ecology 16 (1): 11. https://doi.org/10.1186/s424 08-020-0070-8.

Higuera, P.E., and J.T. Abatzoglou. 2021. Record-setting climate enabled the extraordinary 2020 fire season in the western United States. Global Change Biology 27 (1): 1-2. https://doi.org/10.1111/gcb.15388.

Hill, J.E., T.L. DeVault, J.C. Beasley, O.E. Rhodes, and J.L. Belant. 2018. Effects of vulture exclusion on carrion consumption by facultative scavengers. Ecology and Evolution 8 (5): 2518-2526. https://doi.org/10.1002/ece3.3840.

Hing, S., K.L. Jones, C. Rafferty, R.C.A. Thompson, E.J. Narayan, and S.S. Godfrey. 2017. Wildlife in the line of fire: evaluating the stress physiology of a critically endangered Australian marsupial after bushfire. Australian Journal of Zoology 64 (6): 385-389. https://doi.org/10.1071/ZO16082.

Hing, S., E.J. Narayan, R.C.A. Thompson, and S.S. Godfrey. 2016. The relationship between physiological stress and wildlife disease: consequences for health and conservation. Wildlife Research 43 (1): 51-60. https://doi.org/10.1071/WR15183.

Hossack, B.R., W.H. Lowe, R.K. Honeycutt, S.A. Parks, and P.S. Corn. 2013a. Interactive effects of wildfire, forest management, and isolation on amphibian and parasite abundance. Ecological Applications 23 (2): 479-492. https://doi.org/10.1890/12-0316.1.

Hossack, B.R., W.H Lowe, J.L. Ware, P.S. Corn. 2013b. Disease in a dynamic landscape: host behavior and wildfire reduce amphibian chytrid infection. Biological Conservation 157: 293-299. doi: https://doi.org/10.1016/j.biocon.2012.09.013.

Hradsky, B.A. 2020. Conserving Australia's threatened native mammals in predator-invaded, fire-prone landscapes. Wildlife Research 47 (1): 1-15. https://doi.org/10.1071/WR19027.

Huang, Z.Y.X., F.V. Langevelde, A. Estrada-Peña, G. Suzán, and F.W.D. Boer. 2016. The diversity-disease relationship: evidence for and criticisms of the dilution effect. Parasitology 143 (9): 1075-1086. https://doi.org/10.1017/S0031182016000536.

Hunter, M.E., M.D. Robles. 2020. Tamm review: the effects of prescribed fire on wildfire regimes and impacts: a framework for comparison. Forest Ecology and Management 475: 118435. doi: 10.1016/j.foreco.2020.118435.

Johnson, P.T.J., and D.W. Thieltges. 2010. Diversity, decoys and the dilution effect: how ecological communities affect disease risk. Journal of Experimental Biology 213 (6): 961-970. https://doi.org/10.1242/jeb.037721.

Jolly, W.M., M.A. Cochrane, P.H. Freeborn, Z.A. Holden, T.J. Brown, G.J. Williamson, and D.M.J.S. Bowman. 2015. Climate-induced variations in global wildfire danger from 1979 to 2013. Nature Communications 6 (1): 7537. https://doi. org/10.1038/ncomms8537.

Jones, K.E., N.G. Patel, M.A. Levy, A. Storeygard, D. Balk, J.L. Gittleman, and P. Daszak. 2008. Global trends in emerging infectious diseases. Nature 451 (7181): 990-993. https://doi.org/10.1038/nature06536.

Jones, K.L., C. Rafferty, S. Hing, R.C.A. Thompson, and S.S. Godfrey. 2018. Perturbations have minor impacts on parasite dynamics and body condition 
of an endangered marsupial. Journal of Zoology 305 (2): 124-132. https://doi. org/10.1111/jzo.12541.

Joordaan, P.R., A.N. Green, A.B. Woolcock, and J.C.A. Steyl. 2019. Fire-associated injury in the southern rock monitor (Varanus albigularis albigularis). Biawak 13 (1): $43-45$.

Jorge, M.H., E.P. Garrison, L.M. Conner, and M.J. Cherry. 2020. Fire and land cover drive predator abundances in a pyric landscape. Forest Ecology and Management 461: 117939. https://doi.org/10.1016/j.foreco.2020.117939.

Kays, R., M.C. Crofoot, W. Jetz, and M. Wikelski. 2015. Terrestrial animal tracking as an eye on life and planet. Science 348(6240): aaa2478-aaa2478. https://doi. org/10.1126/science.aaa2478.

Kelly, E.N., D.W. Schindler, V.L.St. Louis, D.B. Donald, and K.E. Vladicka. 2006. Forest fire increases mercury accumulation by fishes via food web restructuring and increased mercury inputs. Proceedings of the National Academy of Sciences 103 (51): 19380-19385. https://doi.org/10.1073/pnas.0609798104.

Kelly, L.T., K.M. Giljohann, A. Duane, N. Aquilué, S. Archibald, E. Batllori, A.F. Bennett, S.T. Buckland, Q. Canelles, M.F. Clarke, M-J. Fortin, V. Hermoso, S. Herrando, R.E. Keane, F.K. Lake, M.A. McCarthy, A. Morán-Ordóñez, C.L. Parr, J. G. Pausas, and L. Brotons. 2020. Fire and biodiversity in the anthropocene. Science 370(6519): eabb0355. doi: https://doi.org/10.1126/science.abb0355. 370, 6519, eabb0355

Kelly, T.R., B.A. Rideout, J. Grantham, J. Brandt, L.J. Burnett, K.L. Sorenson, D. George, A. Welch, D. Moen, J. Rasico, M. Johnson, C. Battistone, and C.K. Johnson. 2015. Two decades of cumulative impacts to survivorship of endangered California condors in California. Biological Conservation 191: 391399. https://doi.org/10.1016/j.biocon.2015.07.012.

Kiss, L., and F. Magnin. 2003. The impact of fire on some Mediterranean land snail communities and patterns of post-fire recolonization. Journal of Molluscan Studies 69 (1): 43-53. https://doi.org/10.1093/mollus/69.1.43.

Kiss, L., and F. Magnin. 2006. High resilience of Mediterranean land snail communities to wildfires. Biodiversity \& Conservation 15 (9): 2925-2944. https://doi.org/10.1007/s10531-005-3430-4.

Kobziar, L.N., and G.R. Thompson. 2020. Wildfire smoke, a potential infectious agent. Science 370 (6523): 1408-1410. https://doi.org/10.1126/science.abe8116.

Korontzi, S., J. McCarty, T. Loboda, S. Kumar, and C. Justice. 2006. Global distribution of agricultural fires in croplands from 3 years of moderate resolution imaging spectroradiometer (MODIS) data. Global Biogeochemical Cycle 20 (2). https://doi.org/10.1029/2005GB002529.

Lydersen, J.M., B.M. Collins, M. Coppoletta, M.R. Jaffe, H. Northrop, and S.L. Stephens. 2019. Fuel dynamics and reburn severity following high-severity fire in a Sierra Nevada, USA, mixed-conifer forest. Fire Ecology 15 (1): 43. https://doi.org/10.1186/s42408-019-0060-x.

MacDonald, A.J., D.W. Hyon, A. McDaniels, K.E. O'Connor, A. Swei, and C.J. Briggs. 2018. Risk of vector tick exposure initially increases, then declines through time in response to wildfire in California. Ecosphere 9 (5): e02227. https://doi. org/10.1002/ecs2.2227.

Mackenzie, J.S., M. Jeggo, P. Daszak, and J.A. Richt. 2013. One Health: the human animal-environment interfaces in emerging infectious diseases: food safety and security, and international and national plans for implementation of One Health activities. Berlin: Springer-Verlag. https:/doi.org/10.1007/978-3-642-35846-3.

Mardiastuti, A. 2020. Response and impact of fire on bird community in the tropical rainforest: a review. IOP Conference Series: Earth and Environmental Science. Vol. 504, 012001. https://doi.org/10.1088/1755-1315/504/1/012001.

Markandya, A., T. Taylor, A. Longo, M.N. Murty, S. Murty, and K. Dhavala. 2008. Counting the cost of vulture decline - an appraisal of the human health and other benefits of vultures in India. Ecological Economics 67 (2): 194-204. https://doi.org/10.1016/j.ecolecon.2008.04.020.

Martin, L.B. 2009. Stress and immunity in wild vertebrates: timing is everything. General and Comparative Endocrinology 163 (1-2): 70-76. https://doi.org/10.1 016/j.ygcen.2009.03.008

McCullough, I.M., K.S. Cheruvelil, J.F. Lapierre, N.R. Lottig, M.A. Moritz, J. Stachelek, and P.A. Soranno. 2019. Do lakes feel the burn? Ecological consequences of increasing exposure of lakes to fire in the continental United States. Global Change Biology 25 (9): 2841-2854. https://doi.org/10.1111/gcb.14732.

McKenzie, D., Z. Gedalof, D.L. Peterson, and P. Mote. 2004. Climatic change, wildfire, and conservation. Conservation Biology 18 (4): 890-902. https://doi. org/10.1111/j.1523-1739.2004.00492.x

McNair, D.B. 1998. Henslow's sparrow and sedge wren response to dormantseason prescribed burn in a pine savanna. Florida Field Naturalist 26 (2): 4647. https://doi.org/10.2307/4090144.
McNeil, D.J., E. McCormick, A.C. Heimann, M. Kammerer, M.R. Douglas, S.C. Goslee, C.M. Grozinger, and H.M. Hines. 2020. Bumble bees in landscapes with abundant floral resources have lower pathogen loads. Scientific Reports 10 (1) 22306. https://doi.org/10.1038/s41598-020-78119-2.

Miller, R.G., R. Tangney, N.J. Enright, J.B. Fontaine, D.J. Merritt, M.J.K. Ooi, K.X. Ruthrof, and B.P. Miller. 2020. Fire seasonality mechanisms are fundamental for understanding broader fire regime effects. Trends in Ecology \& Evolution 35 (10): 869-871. https://doi.org/10.1016/j.tree.2020.08.002.

Morse, S.S., J.A. Mazet, M. Woolhouse, C.R. Parrish, D. Carroll, W.B. Karesh, C. Zambrana-Torrelio, W.I. Lipkin, and P. Daszak. 2012. Prediction and prevention of the next pandemic zoonosis. The Lancet 380 (9857): 1956-1965. https:// doi.org/10.1016/S0140-6736(12)61684-5.

Murray, M.H., C.A. Sánchez, D.J. Becker, K.A. Byers, K.E. Worsley-Tonks, and M.E. Craft. 2019. City sicker? A meta-analysis of wildlife health and urbanization. Frontiers in Ecology and the Environment 17 (10): 575-583. https://doi.org/10.1 002/fee.2126

Mysterud, A., G.R. Rauset, B.V. Moorter, R. Andersen, O. Strand, and I.M. Rivrud. 2020. The last moves: the effect of hunting and culling on the risk of disease spread from a population of reindeer. Journal of Applied Ecology 57 (12): 2509-2518. https://doi.org/10.1111/1365-2664.13761.

Nimmo, D., A. Carthey, C. Jolly, and D.T. Blumstein. 2021. Welcome to the Pyrocene: animal survival in the age of megafire. EcoEvoRxiv. https://doi.org/1 0.32942/osf.io/46zgd.

Ogada, D.L., M.E. Torchin, M.F. Kinnaird, and V.O. Ezenwa. 2012. Effects of vulture declines on facultative scavengers and potential implications for mammalian disease transmission. Conservation Biology 26 (3): 453-460. https://doi.org/1 0.1111/j.1523-1739.2012.01827.x.

Ortega, N. 2018. Flames and frogs - the impact of environmental disturbances on host-parasite dynamics. Dissertation: University of South Florida, USA https:// scholarcommons.usf.edu/etd/7640.

Padgett, K.A., L.E. Casher, S.L. Stephens, and R.S. Lane. 2009. Effect of prescribed fire for tick control in California chaparral. Journal of Medical Entomology 46 (5): 1138-1145. https://doi.org/10.1603/033.046.0522.

Parker-Fann, S.A. 2020. Effectiveness of prescribed burn treatment on forested land as a method to reduce Lyme disease human-contractions in the state of Virginia. Thesis: Johns Hopkins University, Baltimore, Maryland, USA.

Pascoe, E.L., B.T. Plourde, A.M. Lopéz-Perez, and J.E. Foley. 2020. Response of small mammal and tick communities to a catastrophic wildfire and implications for tick-borne pathogens. Journal of Vector Ecology 45 (2): 269-284. https://doi. org/10.1111/jvec.12398.

Pausas, J.G. 2019. Generalized fire response strategies in plants and animals. Oikos, 128(2): 147-153. 128 (2): 147-153. https://doi.org/10.1111/oik.05907.

Pearson, D., K. Ebisu, X. Wu, and R. Basu. 2019. A review of coccidioidomycosis in California: exploring the intersection of land use, population movement, and climate change. Epidemiologic Reviews 41 (1): 145-157. https://doi.org/10.1 093/epirev/mxz004.

Pedersen, A.B., and A. Fenton. 2007. Emphasizing the ecology in parasite community ecology. Trends in Ecology \& Evolution 22 (3): 133-139. https:// doi.org/10.1016/j.tree.2006.11.005.

Perricone, C., M. Versini, D. Ben-Ami, S. Gertel, A. Watad, M.J. Segel, F. Ceccarelli, F. Conti, L. Cantarini, D.P. Bogdanos, A. Antonelli, H. Amital, G. Valesini, and Y. Shoenfeld. 2016. Smoke and autoimmunity: the fire behind the disease. Autoimmunity Reviews 15 (4): 354-374. https://doi.org/10.1016/.jautrev.2016.01.001.

Peters, A., S. Hume, S. Raidal, L. Crawley, and D. Gowland. 2020. Mortality associated with bushfire smoke inhalation in a captive population of the smoky mouse (Pseudomys fumeus): a threatened Australian rodent. Journal of Wildlife Diseases 57 (1): 199-204. https://doi.org/10.7589/JWD-D-20-00026.

Phillips, C.A., A. Caldas, R. Cleetus, K.A. Dahl, J. Declet-Barreto, R. Licker, L.D. Merner, J.P. Ortiz-Partida, A.L. Phelan, E. Spanger-Siegfried, S. Talati, C.H. Trisos, and C.J. Carlson. 2020. Compound climate risks in the COVID-19 pandemic. Nature Climate Change 10 (7): 586-588. https://doi.org/10.1038/541558-0200804-2.

Rohr, J.R., D.J. Civitello, F.W. Halliday, P.J. Hudson, K.D. Lafferty, C.L. Wood, and E.A. Mordecai. 2020. Towards common ground in the biodiversity-disease debate. Nature Ecology \& Evolution 4 (1): 24-33. https://doi.org/10.1038/s41559-019-1 060-6.

Romeo, C., L.A. Wauters, F. Santicchia, B. Dantzer, R. Palme, A. Martinoli, and N. Ferrari. 2020. Complex relationships between physiological stress and endoparasite infections in natural populations. Current Zoology 66 (5): 449457. https://doi.org/10.1093/cz/zoaa029. 
Romero, L.M. 2004. Physiological stress in ecology: lessons from biomedical research. Trends in Ecology \& Evolution 19 (5): 249-255. https://doi.org/10.101 6/j.tree.2004.03.008.

Russell, R.E., J.A. Royle, V.A. Saab, J.F. Lehmkuhl, W.M. Block, and J.R. Sauer. 2009. Modeling the effects of environmental disturbance on wildlife communities: avian responses to prescribed fire. Ecological Applications 19 (5): 1253-1263. https://doi.org/10.1890/08-0910.1.

Sage, M.J.L., B.D. Towey, and J.L. Brunner. 2019. Do scavengers prevent or promote disease transmission? The effect of invertebrate scavenging on Ranavirus transmission. Functional Ecology 33 (7): 1342-1350. https://doi.org/1 $0.1111 / 1365-2435.13335$

Sánchez, C.A., D.J. Becker, C.S. Teitelbaum, P. Barriga, L.M. Brown, A.A. Majewska, R. J. Hall, and S. Altizer. 2018. On the relationship between body condition and parasite infection in wildlife: a review and meta-analysis. Ecology Letters 21 (12): 1869-1884. https://doi.org/10.1111/ele.13160.

Sanchez, J.N., and B.R. Hudgens. 2015. Interactions between density, home range behaviors, and contact rates in the Channel Island fox (Urocyon littoralis). Ecology and Evolution 5 (12): 2466-2477. https://doi.org/10.1002/ece3.1533.

Santangeli, A., M. Girardello, E. Buechley, A. Botha, E.D. Minin, and A. Moilanen. 2019. Priority areas for conservation of Old World vultures. Conservation Biology 33 (5): 1056-1065. https://doi.org/10.1111/cobi.13282.

Scasta, J.D. 2015. Fire and parasites: an under-recognized form of anthropogenic land use change and mechanism of disease exposure. EcoHealth 12 (3): 398 403. https://doi.org/10.1007/s10393-015-1024-5.

Silk, M.J., D.J. Hodgson, C. Rozins, D.P. Croft, R.J. Delahay, M. Boots, and R.A. McDonald. 2019. Integrating social behaviour, demography and disease dynamics in network models: Applications to disease management in declining wildlife populations. Philosophical Transactions of the Royal Society B: Biological Sciences 374 (1781): 20180211. https://doi.org/10.1098/rstb.2018.0211.

Silveira, L., A.T.D.A. Jácomo, J.A.F.D. Filho, and F.H.G. Rodrigues. 1999. Impact of wildfires on the megafauna of Emas National Park, central Brazil. Oryx 33 (2) 108-114. https://doi.org/10.1046/j.1365-3008.1999.00039.x.

Simler-Williamson, A.B., M.R. Metz, K.M. Frangioso, and D.M. Rizzo. 2021. Wildfire alters the disturbance impacts of an emerging forest disease via changes to host occurrence and demographic structure. Journal of Ecology 109 (2): 676691. https://doi.org/10.1111/1365-2745.13495.

Smith, J.E., and N. Pinter-Wollman. 2020. Observing the unwatchable: Integrating automated sensing, naturalistic observations and animal social network analysis in the age of big data. Journal of Animal Ecology 90: 62-75. https:// doi.org/10.1111/1365-2656.13362.

Sokos, C., P. Birtsas, K.G. Papaspyropoulos, E. Tsachalidis, A. Giannakopoulos, C. Milis, V. Spyrou, K. Manolakou, G. Valiakos, C. lakovakis, L.V. Athanasiou, A. Sfougaris, and C. Billinis. 2016. Mammals and habitat disturbance: the case of brown hare and wildfire. Current Zoology 62 (5): 421-430. https://doi.org/10.1 093/cz/zow020

Steel, Z.L., B. Campos, W.F. Frick, R. Burnett, and H.D. Safford. 2019. The effects of wildfire severity and pyrodiversity on bat occupancy and diversity in firesuppressed forests. Scientific Reports 9 (1): 16300. https://doi.org/10.1038/s41 598-019-52875-2.

Steenvoorden, J., A.J.H. Meddens, A.J. Martinez, L.J. Foster, and W.D. Kissling. 2019 The potential importance of unburned islands as refugia for the persistence of wildlife species in fire-prone ecosystems. Ecology and Evolution 9 (15): 8800-8812. https://doi.org/10.1002/ece3.5432.

Stephens, S.L., A.L. Westerling, M.D. Hurteau, M.Z. Peery, C.A. Schultz, and S. Thompson. 2020. Fire and climate change: conserving seasonally dry forests is still possible. Frontiers in Ecology and the Environment 18 (6): 354-360. https://doi.org/10.1002/fee.2218.

Stillman, A.N., R.B. Siegel, R.L. Wilkerson, M. Johnson, and M.W. Tingley. 2019. Agedependent habitat relationships of a burned forest specialist emphasise the role of pyrodiversity in fire management. Journal of Applied Ecology 56 (4): 880-890. https://doi.org/10.1111/1365-2664.13328.

Strandin, T., S.A. Babayan, and K.M. Forbes. 2018. Reviewing the effects of food provisioning on wildlife immunity. Philosophical Transactions of the Royal Society of London. Series B, Biological Sciences 373(1745). 373 (1745): 20170088. https://doi.org/10.1098/rstb.2017.0088.

Sweeny, A.R., C.A. Thomason, E.A. Carbajal, C.B. Hansen, A.L. Graham, and A.B. Pedersen. 2020. Experimental parasite community perturbation reveals associations between Sin Nombre virus and gastrointestinal nematodes in a rodent reservoir host. Biology Letters 16 (12): 20200604. https://doi.org/10.1 098/rsbl.2020.0604
Taylor, M.A., R.L. Coop, and R.L. Wall, eds. 2015. Parasites of ungulates. Pages 761 815 in Veterinary parasitology. Hoboken: John Wiley \& Sons, Inc.. https://doi. org/10.1002/9781119073680.ch14.

Telfer, S., X. Lambin, R. Birtles, P. Beldomenico, S. Burthe, S. Paterson, and M. Begon. 2010. Species interactions in a parasite community drive infection risk in a wildlife population. Science 330 (6001): 243-246. https://doi.org/10.1126/ science.1190333.

Torre, I., A. Arrizabalaga, C. Feliu, and A. Ribas. 2013. The helminth infracommunities of the wood mouse (Apodemus sylvaticus) two years after the fire in Mediterranean forests. Helminthologia 50 (1): 27-38. https://doi. org/10.2478/s11687-013-0104-8.

Torre, l., and M. Díaz. 2004. Small mammal abundance in Mediterranean post-fire habitats: a role for predators? Acta Oecologica 25 (3): 137-142. https://doi. org/10.1016/j.actao.2003.10.007.

Urbanski, S.P., W.M. Hao, and S. Baker. 2008. Chemical composition of wildland fire emissions. In Developments in Environmental Science, ed. A. Bytnerowicz, M.J. Arbaugh, A.R. Riebau, and C. Andersen, vol. 8, 79-107. Amsterdam: Elsevier. https://doi.org/10.1016/S1474-8177(08)00004-1.

Vermeire, M.-L., J. Thoresen, K. Lennard, S. Vikram, K. Kirkman, A.M. Swemmer, M. Te Beest, F. Siebert, P. Gordijn, Z. Venter, C. Brunel, G. Wolfaard, J.A. Krumins, M.D Cramer, H.-J. Hawkins. 2021. Fire and herbivory drive fungal and bacterial communities through distinct above- and belowground mechanisms. Science of The Total Environment 147189. doi: https://doi.org/1 0.1016/j.scitotenv.2021.147189

Vicente, J., and K. VerCauteren. 2019. The role of scavenging in disease dynamics. In Carrion Ecology and Management (pp. 161-182). Springer International Publishing, ed. P.P. Olea, P. Mateo-Tomás, and J.A. Sánchez-Zapata. https://doi. org/10.1007/978-3-030-16501-7_7.

Wan, H.Y., S.A. Cushman, and J.L. Ganey. 2020. The effect of scale in quantifying fire impacts on species habitats. Fire Ecology 16 (1): 9. https://doi.org/10.1186/ s42408-020-0068-2

Ward, M., A.I.T. Tulloch, J.Q. Radford, B.A. Williams, A.E. Reside, S.L. Macdonald, H.J. Mayfield, M. Maron, H.P. Possingham, S.J. Vine, J.L. O'Connor, E.J. Massingham, A.C. Greenville, J.C.Z. Woinarski, S.T. Garnett, M. Lintermans, B.C. Scheele, J. Carwardine, D.G. Nimmo, and J.E.M. Watson. 2020. Impact of 2019-2020 mega-fires on Australian fauna habitat. Nature Ecology \& Evolution 4 (10): 1321-1326. https://doi.org/10.1038/s41559-020-1251-1.

Weir, J. 2009. Conducting prescribed fires. College Station: Texas A\&M University Press https://www.tamupress.com/9781603441346/conducting-prescribed-fires.

Werner, C.S., and C.L. Nunn. 2020. Effect of urban habitat use on parasitism in mammals: a meta-analysis. Proceedings of the Royal Society B: Biological Sciences 287 (1927). https://doi.org/10.1098/rspb.2020.0397.

Westerling, A.L. 2016. Increasing western US forest wildfire activity: sensitivity to changes in the timing of spring. Philosophical Transactions of the Royal Society B: Biological Sciences 371 (1696): 20150178. https://doi.org/10.1098/ rstb.2015.0178.

Westerling, A.L., H.G. Hidalgo, D.R. Cayan, and T.W. Swetnam. 2006. Warming and earlier spring increase western U.S. forest wildfire activity. Science 313 (5789): 940-943. https://doi.org/10.1126/science.1128834.

White, L.A., J.D. Forester, and M.E. Craft. 2018. Dynamic, spatial models of parasite transmission in wildlife: their structure, applications and remaining challenges. Journal of Animal Ecology 87 (3): 559-580. https://doi.org/1 $0.1111 / 1365-2656.12761$.

Williams, H.J., L.A. Taylor, S. Benhamou, A.I. Bijleveld, T.A. Clay, S. de Grissac, U. Demšar, H.M. English, N. Franconi, A. Gómez-Laich, R.C. Griffiths, W.P. Kay, J.M. Morales, J.R. Potts, K.F. Rogerson, C. Rutz, A. Spelt, A.M. Trevail, R.P. Wilson, and L. Börger. 2020. Optimizing the use of biologgers for movement ecology research. Journal of Animal Ecology 89 (1): 186-206. https://doi.org/1 $0.1111 / 1365-2656.13094$.

Woodroffe, R., C.A. Donnelly, D.R. Cox, F.J. Bourne, C.L. Cheeseman, R.J. Delahay, G. Gettinby, J.P. Mclnerney, and W.I. Morrison. 2006. Effects of culling on badger Meles meles spatial organization: implications for the control of bovine tuberculosis. Journal of Applied Ecology 43 (1): 1-10. https://doi.org/1 0.1111/j.1365-2664.2005.01144.x.

Woolhouse, M.E.J. 2006. Where do emerging pathogens come from? Microbe Magazine 1 (11): 511-515. https://doi.org/10.1128/microbe.1.511.1.

\section{Publisher's Note}

Springer Nature remains neutral with regard to jurisdictional claims in published maps and institutional affiliations. 